\title{
A delicate balance: iron metabolism and diseases of the brain
}

\author{
Dominic Hare ${ }^{1,2 t}$, Scott Ayton ${ }^{1 \dagger}$, Ashley Bush ${ }^{1}$ and Peng Lei ${ }^{1 *}$ \\ 'The Florey Institute of Neuroscience and Mental Health, University of Melbourne, VIC, Australia \\ ${ }^{2}$ Elemental Bio-imaging Facility, University of Technology, Sydney, NSW, Australia
}

Edited by:

Anthony Robert White, The University of Melbourne, Australia

\section{Reviewed by:}

Jose G. Castaño, Universidad

Autónoma de Madrid, Spain

Jurgen Gotz, The University of

Sydney, Australia

\section{${ }^{*}$ Correspondence:}

Peng Lei, The Florey Institute of

Neuroscience and Mental Health,

Level 4 Kenneth Myer Building,

University of Melbourne, VIC 3010,

Australia

e-mail: peng.lei@florey.edu.au

${ }^{\dagger}$ Dominic Hare and Scott Ayton have

contributed equally to this work.
Iron is the most abundant transition metal within the brain, and is vital for a number of cellular processes including neurotransmitter synthesis, myelination of neurons, and mitochondrial function. Redox cycling between ferrous and ferric iron is utilized in biology for various electron transfer reactions essential to life, yet this same chemistry mediates deleterious reactions with oxygen that induce oxidative stress. Consequently, there is a precise and tightly controlled mechanism to regulate iron in the brain. When iron is dysregulated, both conditions of iron overload and iron deficiencies are harmful to the brain. This review focuses on how iron metabolism is maintained in the brain, and how an alteration to iron and iron metabolism adversely affects neurological function.

\section{Keywords: iron regulation, Alzheimer's disease, Parkinson's disease, iron deficiency, iron chelation}

\section{INTRODUCTION}

Iron is a fundamental requirement for most known life forms, and is likely to have played an integral role in the earliest development of life on this planet (Russell et al., 1993). Organisms have evolved to harness the unique chemistry of this highly abundant metal, which make it integral to a vast array of chemical reactions supporting cell division, oxygen transport and mitochondrial function. The iron redox couple mediates the transfer of single electrons through the reversible oxidation/reduction reactions of $\mathrm{Fe}^{2+}$ and $\mathrm{Fe}^{3+}$. Iron is a $d$-block transition metal, and the unoccupied $d$-orbitals allow ionic iron (II), iron (III), and iron (IV) species to form ligands with both small and large biomolecules via oxygen, nitrogen, and sulfur atoms. The biological redox potential and electronic spin state, and thereby reactivity

Abbreviations: AD, Alzheimer's disease, ADHD, attention deficit hyperactivity disorder; apo-Tf, apo-transferrin; ATP, adenosine-5'-triphosphate; BBB, bloodbrain barrier; BCEC, brain capillary endothelial cells; BID, brain iron deficiency; cAMP, cyclic adenosine monophosphate; $\mathrm{Cp}$, Ceruloplasmin; CREB, cyclic adenosine monophosphate response element-binding protein; CSF, cerebrospinal fluid; DMT1, divalent metal transporter 1; Fe, iron; Fe2Tf/holoTf, holo-transferrin; GWAS, genome-wide association study; HCP1, heme carrier protein 1; HFE, human hemochromatosis protein; HIF, hypoxia inducible factor; ICP-MS, inductively coupled plasma-mass spectrometry; IRE, iron responsive element; IRP1/2, iron regulatory proteins $1 / 2$; LMW, low molecular weight; MMSE, mini-mental state examination; MPTP, methyl-4-phenyl-1,2,3,6-tetrahydropyridine; MRI, magnetic resonance imaging; mRNA, messenger RNA; NBIA, neurodegeneration with brain iron accumulation; NTBI, non-transferrin bound iron; 6-OHDA, 6hydroxydopamine; PD, Parkinson's disease; RLS, restless legs syndrome; ROS, reactive oxygen species; $\mathrm{SN}$, substantia nigra; STEAP 1-4, six-transmembrane epithelial antigen of prostate 1-4; TCS, transcranial sonography; Tf, transferrin; TFR1, transferrin receptor 1; TfR2, transferrin receptor 2; UTR, unstranslated region; MAPK, mitogen-activated protein kinase; Erk1/2, extracellular signalregulated kinase 1/2; GSK-3, glycogen synthase kinase 3; Cdk-5, cyclin-dependent kinase 5; AMPA, $\alpha$-amino-3-hydroxy-5-methyl-4-isoxazolepropionic acid; Bcl-2, B-cell lymphoma 2; NMDA, $N$-methyl-D-aspartate. of iron, is determined by the nature of the ligand to which the species is bound. This configuration, along with the oxidation state of the iron itself, dictates whether an iron-based biomolecule is responsible for reactions involving oxygen transport and storage, electron transfer, or oxidation/reduction of other molecules (Beard, 2001). Reactions involving iron in the body are predominately redox-based, hydrolytic or involve polynuclear complex formation (Aisen, 2001).

Reliance upon iron for normal physiological function has thus necessitated a tightly regulated mechanism for ensuring the net turnover of dietary iron is essentially neutral (Crichton and Ward, 1992). This is especially important for the brain, where some of the highest concentrations of iron in the body are maintained (Gerlach et al., 1994). This review will provide an overview of how brain iron metabolism is regulated, and the consequences of perturbed iron homeostasis.

\section{IRON UPTAKE, TRANSPORT AND CELLULAR REGULATION IRON CIRCULATION AND BRAIN UPTAKE}

The major iron transporter protein in the body is the $80 \mathrm{kDa}$ glycoprotein transferrin (Tf). Each bi-lobar molecule, consisting of two globular units at the $\mathrm{N}$ - and $\mathrm{C}$-terminals has two iron-binding sites, which form a 4 -atom tetradentate ligand via histidine, aspartate, and two tyrosine amino acid residues (Anderson et al., 1987). Almost all iron exchange and transport within the body is mediated by Tf (Finch and Huebers, 1982), with around 3-4 mg of iron typically circulating the healthy adult bound to $\mathrm{Tf}$. Two $\mathrm{Fe}^{3+}$ ions oxidized by a ferroxidase and shunted into the interstitium by ferroportin are loaded onto a single Tf unit, and at any one time only around $30 \%$ of all circulating Tf units are occupied (only in cases of severe iron overload does Tf saturation occur; Aisen, 2001). Less than $1 \%$ of circulating iron is usually non-Tf bound. Non-Tf 
bound iron (NTBI) is handled by a series of low molecular weight (LMW) ligands including citrate and ascorbate ions, as well as a possible small contribution from circulating albumin and ferritin proteins (Breuer et al., 2000) and ATP.

The hydrophobic barricade formed by the blood-brain barrier (BBB) prevents diffusion of hydrophilic $\mathrm{Fe}_{2} \mathrm{Tf}$ into the nervous system, as well as prevent migration of NTBI. Moos et al. (2007) and Crichton et al. (2011) have recently published comprehensive pictures of iron trafficking within the brain, including uptake from the periphery. This step, where $\mathrm{Fe}_{2} \mathrm{Tf}$ is transported across the BBB through brain capillary endothelial cells (BCECs). Tf-uptake into BCECs follows an endocytotic mechanism, where circulating $\mathrm{Tf}$ binds to $\mathrm{Tf}$ receptors which then internalize. It is a point of contention as to whether iron export from the endosome is mediated by the protein divalent metal transporter-1 (DMT1); conflicting reports have either identified (Burdo et al., 2001) or failed to identify (Moos and Morgan, 2004) DMT1 in rodent brain BCECs. An alternative hypothesis has suggested iron becomes segregated from Tf after liberation from the metal-protein complex in the endosome and is released independently of DMT1 (Moos et al., 2006). During development, when the BBB is not fully formed, there is a rapid influx of iron most likely stemming from NTBI; the developing rat brain shows a rapid intake of iron in line with increased expression of transferrin receptor 1 (TfR1) in BCECs, which in turn becomes the major iron regulatory mechanism once the $\mathrm{BBB}$ is sealed, after which iron intake slows (Taylor and Morgan, 1990). However, brain iron import is unlikely solely regulated by BCECs, like many other metabolic pathways redundancies are likely in place in the case one pathway breaks down. For instance, obstruction of BCEC TfR1 in mice and rats using intravenously administered monoclonal antibodies did not completely impede brain iron uptake (Ueda et al., 1993).

A possible alternative mechanism for the uptake of NTBI may be associated with the expression of ferroportin in the BBB (Wu et al., 2004) and circulating ferroxidases (enzymes that catalyze $\mathrm{Fe}^{2+}$ oxidation to $\mathrm{Fe}^{3+}$ ) like ceruloplasmin (Cp; Osaki et al., 1966). It should be noted, however, that expression of ferroportin in BCECs has been disputed (Moos and Rosengren Nielsen, 2006). It is also unclear as to whether iron present in the BCEC endosome is in fact released into the cytosol. Moos et al. (2007) proposed that the possible lack of DMT1 is suggestive that the endosome traverses the BCEC cytosol intact (transcytosis) and releases $\mathrm{Fe}^{3+}$ directly into the brain for distribution to cells.

On the abluminal side of the BCEC astrocytes abut the cell membrane, forming part of either "neurovascular" or "gliovascular" units comprising of neurons, astrocytes, and BCECs (Abbott et al., 2006). Moos et al. (2007) suggested that astrocyte "end feet" surround the BCEC with a thin layer of interstitial fluid into which iron is released from endosomal $\mathrm{Fe}_{2} \mathrm{Tf}-\mathrm{TfR} 1$ complexes on the luminal membrane of the BCEC. Iron is then either re-complexed by Tf in the brain interstitium, or bound to LMW ligands released by the astrocyte. While the affinity of iron to small ligands is considerably smaller than that to $\mathrm{Tf}$, it has been suggested that $\mathrm{Tf}$ saturation in the cerebrospinal fluid (CSF) is much higher than in the periphery, and that a larger proportion of NTBI circulates the nervous system (Leitner and Connor, 2012). Astrocytes also provide a source of $\mathrm{Cp}$ to ensure any circulating $\mathrm{Fe}^{2+}$ is quickly oxidized to $\mathrm{Fe}^{3+}$ to prevent unwanted reactive oxygen species (ROS) production through Fenton chemistry.

\section{CELLULAR IRON TRAFFICKING IN THE BRAIN}

Iron is released from Tf into cells via a particularly elegant mechanism. TfR 1 is a ubiquitously expressed membrane protein with a dimeric structure and high affinity to $\mathrm{Fe}_{2} \mathrm{Tf}$, but at neutral $\mathrm{pH}$, has a low affinity for apo-Tf (iron-free) so that the unligated Tf does not act as a competitive inhibitor of holo-Tf (iron-bound) uptake (Aisen, 2004). The $\mathrm{Fe}_{2}$ Tf forms a complex with the TfR1 receptor, which is then endocytosed. A proton pump mechanism is initiated to lower the $\mathrm{pH}$ within the endosome, which causes a conformational change to both the $\mathrm{Fe}_{2} \mathrm{Tf}$ and TfR 1 units, in turn resulting in release of the iron from its chaperoning protein (Hentze et al., 2004). The newly freed $\mathrm{Fe}^{3+}$ is quickly reduced by the six-transmembrane epithelial antigen of prostate 1-4 (STEAP $1-4)$, allowing export from the endosome into the cytosol by DMT1 (De Domenico et al., 2008). In the acidic endosome, apo-Tf has a strong affinity for the Tf receptor; this interaction prevents the degradation of free Tf when the endosome complexes with the lysosome before exocytosis. During exocytosis the $\mathrm{pH}$ returns to neutral, which causes dissociation of the apo-Tf from the TfR1, effectively recycling the $\mathrm{Tf}$ molecule for further use in iron circulation (Dautry-Varsat et al., 1983). In 1999, a homolog Tf receptor, TfR2, was identified (Kawabata et al., 1999), which initially showed expression only in hepatocytes, duodenal crypt cells, and erythrocytes. TfR2 has a 30-fold lower affinity to iron-bound Tf, yet mutations to the TfR2 gene results in hereditary hemochromatosis (Camaschella et al., 2000). TfR2 shares 45\% amino acid identity with the ubiquitous TfR1 (Kawabata et al., 1999; Fleming et al., 2000). Interestingly, TfR2 has also been identified in dopaminergic neurons, and has been suggested to play a role in $\mathrm{Fe}_{2} \mathrm{Tf}$ translocation to mitochondria (Mastroberardino et al., 2009).

Neurons express both TfR1 and DMT1 (Burdo et al., 2001), and therefore uptake iron via a receptor-mediated endocytotic mechanism (Figure 1), though it is likely that a small minority of iron uptake is sourced from NTBI in vivo. Astrocytes are devoid of TfR1, and NTBI is most likely their major iron source (Moos and Morgan, 2004). Oligodendrocytes, which require iron for myelin synthesis (see below; Connor and Menzies, 1998) also import iron through a mechanism independent of TfR1. Two noteworthy hypotheses have been proposed to explain how the comparatively high need for iron by oligodendrocytes is regulated without the major iron import mechanism present. Firstly, iron passes into the cytosol complexed with LMW ligands. Iron is then incorporated into Tf produced within the oligodendrocyte itself, where it is either used immediately or sequestered in ferritin for storage (Moos et al., 2007). Tf is not secreted by the oligodendrocyte itself (de Arriba Zerpa et al., 2000), presenting a fairly unique closed environment of iron regulation in what is predominately otherwise an intertwined regulatory system.

Once inside the cell, iron can follow multiple pathways dependent on need. Ferritins are responsible for iron storage and play an integral role in iron homeostasis, and are rarely saturated due to their large capacity for thousands of individual $\mathrm{Fe}^{3+}$ ions (Theil, 2004). Numerous other cytosolic proteins require iron for a variety 


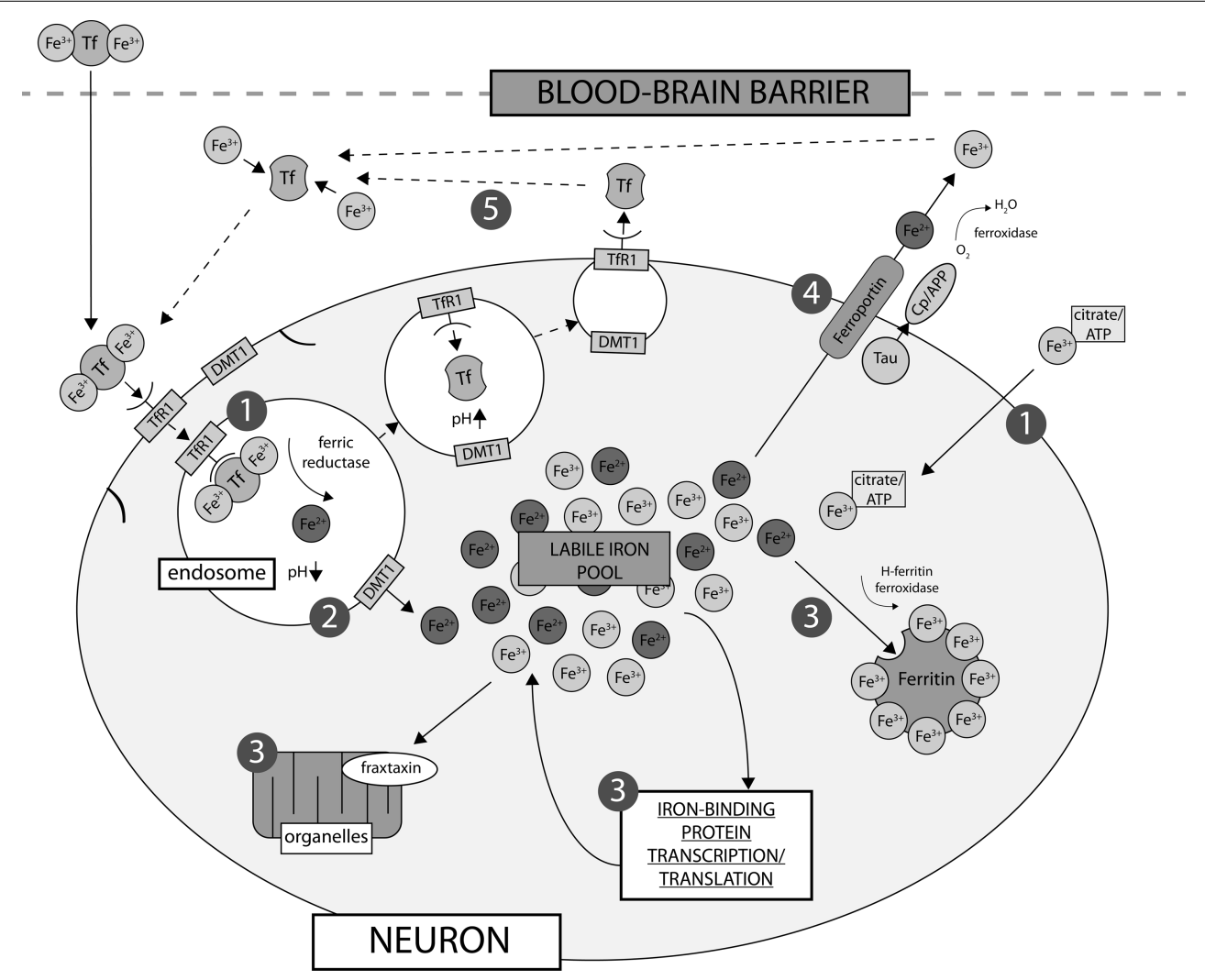

FIGURE 1 | Neuronal iron uptake and export. Iron is imported into the cell either as low molecular weight complexes with citrate/ATP, or via transferrin receptor (TfR1)-mediated endocytosis (1). Export of iron from the endosome via divalent metal transporter-1 (DMT-1) directly contributes to the labile iron pool (2), which constitutes the available iron content of the neuron and is regulated by cellular metal sensing and iron-binding protein expression, including ferritin, which is the major iron storage protein in neurons (3). Export of iron from neurons is regulated by intramembrane ferroportin, which is stabilized via a mechanism involving tau and ceruloplasmin (Cp)/APP (4). Iron is then recirculated by apo-Tf (5). of normal functions. Iron is also important to mitochondrial functions, where it is incorporated into $\mathrm{Fe}-\mathrm{S}$ clusters and heme proteins (Hentze et al., 2004). The mechanism for mitochondrial uptake has not been categorically confirmed, though the two proposed pathways involve either (i) diffusion of NTBI or (ii) direct translocation of extracellular $\mathrm{Fe}_{2} \mathrm{Tf}$ via an endosomal pathway (Horowitz and Greenamyre, 2010). Within the mitochondria, the frataxin protein (implicated in Friedreich's ataxia) is suggested to act as a intramitochondrial iron chaperone (Richardson et al., 2010).

The only known export pathway in mammalian cells is mediated via ferroportin (Ganz, 2005). Ferroportin allows ferrous iron to be transported out of the cell (Donovan et al., 2005), and this process requires a ferroxidase to oxidize the ferrous iron to ferric, so that $\mathrm{Tf}$ can bind the exported iron. In the brain, ferroportin has been identified in both neurons (Abboud and Haile, 2000) and astrocytes (Dringen et al., 2007), as have the corresponding ferroxidases, the amyloid precursor protein (APP; Duce et al., 2010) and Cp (Texel et al., 2011).

\section{REGULATION OF IRON-ASSOCIATED PROTEINS}

Iron-associated proteins are regulated by iron status, therefore form a cycle to regulate iron metabolism (Figure 2). In cases of low cellular iron, two iron regulatory proteins (IRP1/2) are free to bind directly with iron responsive element (IRE) stem-loop structures within the mRNA of iron-binding proteins. The $3^{\prime}$ untranslated portion of, for example, TfR1 mRNA is sensitive to ribonuclease degradation, thus binding with IRP1/2 protects the mRNA and promotes TfR1 expression, increasing cellular iron uptake. Conversely, binding of IRP $1 / 2$ to the $5^{\prime}$ untranslated region (UTR) of, for example, ferritin mRNA prevents translation, reducing cytoplasmic ferritin expression, reducing the iron storage capacity of the cell, and increasing available iron (Aisen, 2001). When iron levels in the cell are high, labile iron binds with IRP1/2, preventing interactions between the regulatory proteins and the IREs in the mRNA of various iron regulating proteins (see Figure 2), eliciting the reverse cellular response to that observed in cases of iron deficit. The mechanism of iron-mediated inhibition of IRP/IRE binding depends on the protein involved: IRP1-Fe undergoes a conformational change that prevents IRE binding, whereas IRP2Fe complexes undergo degradation via the ubiquitin proteasome pathway (Pantopoulos, 2004). Both IRP1 and IRP2 are present in the rat (Siddappa et al., 2003) and human brain (Connor et al., 1992c); IRP1 has been suggested as the primary regulatory protein in the human brain and is capable of forming a double IRP1/IRE complex (Hu and Connor, 1996). 


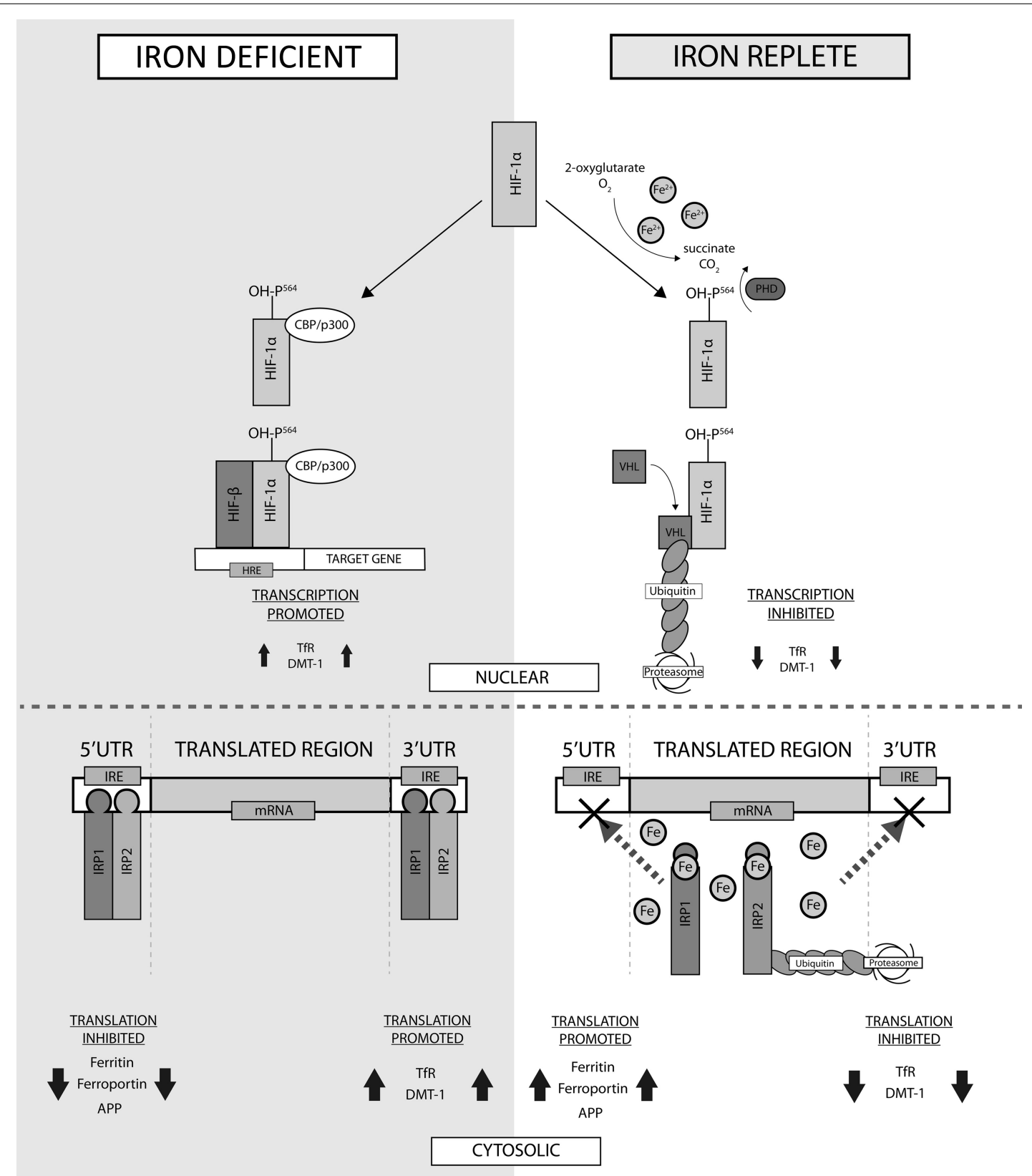

FIGURE 2 | Factors influencing cellular iron metabolism. Cellular oxygen homeostasis regulates iron metabolism in the nucleus via the hypoxia inducible factors (HIF-1 $\alpha$ and $-1 \beta$ ). In normoxia conditions, $\mathrm{Fe}^{2+}$ mediates the hydroxylation of proline residue 546 on HIF-1 $\alpha$ by prolyl-4-hydroxylase (PHD), which enables ubiquitination via binding with the von Hippel-Lindau tumor suppressor gene product (VHL). Decreased HIF-1 a inhibits transcription of proteins dictating iron uptake and export. In the iron-deficient cell, HIF-1 $\alpha$ instead interacts with CREB binding protein/p300 (CBP/p300) and forms a heterodimer with HIF-1 $\beta$, activating transcription of target genes possessing hypoxia response elements. In the cytosol, the iron replete cell prevents the binding of iron responsive proteins (IRP) -1 and -2 to the iron responsive elements (IREs) in the $5^{\prime}$ and $3^{\prime}$ untranslated region (UTR) of $m R N A$, inhibiting the transcription of uptake proteins and promoting expression of proteins involved in iron export. In cases of iron deficiency, IRPs directly interact with the $5^{\prime}$ - and $3^{\prime}-U T R s$, eliciting the reverse effect. TfR, transferrin receptor; DMT-1, divalent metal transporter-1; APP, amyloid precursor protein.
Iron metabolism is also transcriptionally regulated by the action of hypoxia inducible factors (HIFs; see Figure 2), which consists of a cytosolic protein (HIF-1 $\alpha$ ) and a nuclear HIF- $1 \beta$ subunit that form a DNA binding heterodimer (Peyssonnaux et al., 2008). HIF- $1 \alpha$ levels are dictated by cellular chemistry, and in normal conditions HIF- $1 \alpha$ is hydroxylated by prolyl hydroxylase, marking the adduct for ubiquitination and degradation (Ratcliffe et al., 1999). This reaction requires oxygen, 2-oxoglutarate, ascorbate, and iron as cofactors. In hypoxic conditions HIF- $1 \alpha$ ubiquitination is inhibited and translocation to the nucleus is increased, where dimerization with HIF- $1 \beta$ allows binding with cyclic adenosine monophosphate (cAMP) response element-binding protein 
(CREB), which activates transcription of target genes with hypoxia response elements (HREs; Semenza, 2000). As iron is necessary for hydroxylation of HIF- $1 \alpha$, any decrease in cellular iron levels will increase dimerization of HIF- $1 \alpha$ and $\beta$ and downstream transcription of target genes, which, unsurprisingly, includes those responsible for Tf (Rolfs et al., 1997), TfR1 (Lok and Ponka, 1999), and DMT1 (Lis et al., 2005).

With such a sophisticated regulation mechanism for regulating iron-associated proteins transcription and translation, it is surprising diseases of iron overload and deficiencies exist. Some of these disorders arise from nutritional deficiency/excess or genetic mutation in one or more iron-associated proteins. But as will be described, the disorders of iron metabolism are invariably chronic disorders, not acute disorders. Possibly because there is complex regulatory mechanism that can resist, and then compensate for, short-term changes to iron levels.

\section{IRON FLUX AND DEFICIENCY}

Iron deficiency is a major nutrition deficiency most often observed in the developing world. Even in a developed nation, such as the USA, approximately $10 \%$ of toddlers and women of childbearing age are iron-deficient (Looker et al., 1997). As described above, the cellular iron regulatory mechanism is nuanced and robust, therefore allowing considerable divergence from the homeostatic norm of iron levels before disease precipitates. Disorders of iron homeostasis are thus invariably chronic, not acute diseases. This is especially true of the brain, which has more stable iron levels compared to the other organs (Youdim et al., 1989).

Peripheral iron deficiency can result in minor to severe symptoms. Anemia is an advanced iron deficiency syndrome caused by a number of factors ranging from dietary deficiency, blood loss, and metabolic lesions. The most common symptoms arising from anemia result from reduced oxygen transportation by hemoglobin. These symptoms include pallor, fatigue, faintness, shortness of breath, muscle weakness, angina pain, and elevated cardiac output (as compensation for reduced oxygen carrying capacity; Wood and Elwood, 1966).

While symptoms of anemia can arise over a period of weeks to months, iron in the brain is more resistant to dietary changes (Youdim et al., 1989) and indeed the brain may have critical periods that determine the level of iron in the brain throughout life (Dallman etal., 1975; Dallman and Spirito, 1977; Ben-Shachar et al., 1986). The brain accumulates iron during the weaning period, which establishes an iron "set point" for the brain. Perinatal pups on a restricted iron diet cannot recover their brain iron levels when supplemented later in life (Ben-Shachar et al., 1986). It has been proposed that the brain of a post-weaned mammal is impermeable to peripheral iron (Kaur et al., 2007), possibly explaining why brain iron levels are not easily altered with diet (Ben-Shachar et al., 1986). However, supplementation of isotopically enriched iron to mice reveals dietary iron incorporation into the brain at a similar rate to other organs (Chen et al., 2013). Peripheral iron is able to enter the brain by patterning with Tf, which can undergo receptor-mediated transcytosis to pass through the BBB (Fishman et al., 1987; Bradbury, 1997; Morgan and Moos, 2002). It is likely that brain iron is in constant flux with peripheral pools of iron. We speculate that brain iron levels do not tangibly deviate from the norm despite changes in the diet, because the brain iron levels are strictly governed by the iron homeostatic mechanism, and where the normal level of iron in the brain for an adult individual is likely determined in the critical weaning period of the mammal. This period can thus shape the iron biochemistry of the brain throughout the life of an individual, highlighting the urgency of addressing nutritional deficiency in infants raised in areas of poverty. Described below, chronic brain iron deficiency disrupts important process in the brain, altering neurochemistry that eventually leads to disease.

\section{NEUROCHEMICAL EFFECT OF IRON DEFICIENCY NEUROTRANSMITTER SIGNALING}

Iron affects synthesis and signaling of the neurotransmitters dopamine, noradrenalin, adrenaline and 5-hydroxytryptamine, which are involved in emotion, attention, reward, movement, and various other functions. These neurotransmitters are synthesized by a number of iron-dependent enzymes including phenylalanine hydroxylase (Gottschall et al., 1982), tyrosine hydroxylase (Ramsey et al., 1996), and tryptophan hydroxylase (Kuhn et al., 1980). Brain iron deficiency (BID), however, rarely causes reduced expression or activity of these enzymes (Youdim et al., 1989). The conservation of iron in these enzymes under BID possibly reflects the importance of these enzymes to brain function.

In addition to neurotransmitter synthesis, iron impacts several other steps in neurotransmitter signaling, which are more vulnerable to changes in iron levels. Reduced neuronal uptake of the catecholaminergic neurotransmitters has been observed in several BID models (Burhans et al., 2005; Beard et al., 2006b; Bianco et al., 2008), and the extracellular concentration of neurotransmitters are elevated in BID rats (Beard et al., 1994). Dopaminergic signaling is further perturbed in iron deficiency by attenuating affinity and expression of D2 neurotransmitters (Youdim et al., 1989).

\section{ENERGY PRODUCTION}

The brain has a high energy demand, accounting for $20 \%$ of basal oxygen consumption (Halliwell, 2006) and thus requires high iron levels to generate ATP by the electron transport chain in the mitochondria. Various mitochondrial enzymes utilize iron as a cofactor including the mitochondrial ferredoxins (Redfearn and King, 1964), cytochromes (Slater, 1949), and aconitase (Dickman and Cloutier, 1950). Iron deficiency changes mitochondria morphology (Jarvis and Jacobs, 1974), impairs function (Masini et al., 1994), and damages mitochondrial DNA (Walter et al., 2002). Reduced mitochondrial efficiency possibly explains why iron deficiency results in elevation of oxidative stress markers (Knutson et al., 2000; Jeong et al., 2011; Wan et al., 2012a), despite loss of pro-oxidant iron.

\section{MYELINATION}

Myelin is the fatty "white matter" that insulates axons and preserves their signaling. Accordingly, under basal conditions, oligodendrocytes exhibit high levels of iron comparative to other brain cells (Benkovic and Connor, 1993; Connor et al., 1995). Iron treatment to cultured glial restricted precursor cells increases their differentiation into GalC1 oligodendrocytes, while treatment to cultured $\mathrm{O} 2 \mathrm{~A}$ oligodendrocytes progenitors increases their 
proliferation without altering differentiation (Morath and MayerProschel, 2001). Iron, therefore, has marked, but distinct effects on the temporal sequence of oligodendrocyte development. In a rat model, BID restricts both glia precursor cell proliferation and differentiation into oligodendrocytes (Morath et al., 2002) and decreases components of myelin: myelin basic protein, myelin proteolipid protein, galactolipids, phospholipids, and cholesterol (Yu et al., 1986; Ortiz et al., 2004). Lack of myelination causes slower neuronal conduction, evidenced by retardation of reflexes. In humans, iron deficiency is associated with abnormal reflexes in infants (Armony-Sivan et al., 2004) and in iron-deficient children, deficits in auditory brain stem potentials and visual evoked potentials have been observed (Roncagliolo et al., 1998; Algarin et al., 2003).

\section{NEUROLOGICAL DISORDERS ASSOCIATED WITH IRON DEFICIENCY FAILURE TO THRIVE}

It is now widely recognized that BID in early life is associated with developmental delays in various brain faculties. Iron deficiency, characterized by anemia, has been associated with poorer fine and gross motor skills, visual-motor integration, language and global IQ, accompanying higher scores in anxiety and depression, social and attention problems (Palti et al., 1985; Lozoff et al., 1991; Hurtado et al., 1999) with some symptoms persisting 10 years after treatment for anemia (Lozoff et al., 2000). While the association between iron and various markers of developmental delay are unequivocal, the causal relationship is complicated by confounding socioeconomic variables that often accompany iron deficiency including generally poor nutrition, lack of stimulation in the home, lack of maternal warmth, poor maternal education, maternal depression, more absent fathers, parasitic infection, and low birth weight (Grantham-McGregor and Ani, 2001).

The importance of iron to neurodevelopment is thus unclear from observational human studies, which has necessitated study of iron-deficient experimental animal models. Agreeing with complementary human studies, BID in rats causes delayed behavioral milestones (Beard et al., 2006a), including impaired memory (Yehuda et al., 1986; Wachs et al., 2005) and motor function (Hunt et al., 1994). Symptoms resulting from dietary iron restriction in the first 21 days of the life of the rat are not recoverable even after 6 weeks of iron supplementation (Ben-Shachar et al., 1986). Combining the human and animal evidences strongly supports a critical role for iron in neurodevelopment, and since the symptoms are not readily correctable after the critical period, these also highlight the importance of monitoring and early dietary intervention.

\section{ATTENTION DEFICIT HYPERACTIVITY DISORDER}

Attention deficit hyperactivity disorder (ADHD) is a developmental disorder manifesting in symptoms of inattention, hyperactivity, and impulsiveness. ADHD is highly heritable, and several candidate disease-causing genes are involved in dopamine neurotransmission (DAT1, DRD4, DRD5; Elia and Devoto, 2007). Since iron interacts with multiple steps in dopamine neurotransmission, it is possible that BID might precipitate ADHD in idiopathic cases. While several studies showed reduced ferritin in children affected by ADHD (Konofal et al., 2004; Oner et al., 2008; Cortese et al.,
2009; Juneja et al., 2010; Menegassi et al., 2010), the largest study (194 children), reported unaltered serum ferritin levels between ADHD patients and controls (Donfrancesco et al., 2012). As previously mentioned, iron status in children often co varies with multiple parameters of socioeconomic status, which might confound these studies. Further peripheral markers of iron do not often reflect the status of brain iron; therefore peripheral iron is not likely altered in ADHD. However, a recent study of 36 individuals reported reduced brain iron in the thalamic region as measured by magnetic resonance imaging (MRI) in ADHD patients (Cortese et al., 2012) suggesting a role for BID in the pathogenesis of this disease.

Could iron supplementation therefore be used as a treatment for ADHD? A case study reported a 3 year-old presenting with low serum ferritin (13 $\mathrm{ng} \mathrm{mL}^{-1}$ ) accompanying ADHD who was supplemented with ferrous sulfate $\left(80 \mathrm{mg} \mathrm{day}^{-1}\right)$ and 8 months later was observed to exhibit various behavioral improvements (Konofal et al., 2005). This prompted a 12 -week clinical trial of iron supplementation in $\mathrm{ADHD}$, which recorded improvements in the ADHD rating scale for the treatment group (Konofal et al., 2008). These studies warrant further investigation into iron as a potential therapeutic, however, as discussed above, iron supplementation after a critical period is not effective in reversing cognitive symptoms of early BID in rats (Ben-Shachar et al., 1986), which might limit the use of this approach in ADHD.

\section{RESTLESS LEGS SYNDROME}

Restless legs syndrome (RLS) is a neurological disorder characterized by uncomfortable or odd sensations in the body (often legs) that prompt an incessant urge to move (Earley, 2003). The prevalence of RLS is estimated to be between 5 and $10 \%$ of the population (Lavigne and Montplaisir, 1994; Rothdach et al., 2000; Ulfberg et al., 2001). The disorder is associated with reduced dopamine uptake and reduced D2 receptor density (Staedt et al., 1995; Turjanski et al., 1999; Michaud et al., 2002), and is often treated with dopamine-based therapies (Hening et al., 1999; Allen et al., 2001). This neurochemical profile is consistent with BID (Youdim et al., 1989) of the nigrostriatal pathway. Indeed low ferritin and high Tf levels have been reported in CSF of RLS patients, while serum indices of iron metabolism were not altered (Earley et al., 2000; Clardy et al., 2006). Direct measurements of iron by post-mortem histological staining (Connor et al., 2003) and MRI (Allen et al., 2001; Earley et al., 2006) reveal decreased levels in the substantia nigra $(\mathrm{SN})$ of affected patients.

\section{NEURODEGENERATION}

What are the lifetime consequences of BID? This remains an underexplored subject in brain iron research, which has historically focused on BID in neurodevelopment, and iron accumulation in neurodegeneration. Accordingly, to our knowledge, there has been no report of BID in a neurodegenerative disorder. Recently, a genetic mouse model of motor neuron iron deficiency (IRP2 ${ }^{-/-}$) exhibited reduced mitochondrial activity, hypomyelination, and neurodegeneration (Jeong et al., 2011), raising the possibility of BID-induced neurodegenerative disorders. Patients with the neurodegenerative disorder, dementia with Lewy bodies (DLB), have a threefold higher incidence of self-reported history of ADHD 
symptoms. However, the status of iron in ADHD patients is only beginning to emerge, and the status of iron in DLB is also not known, so it is premature to mechanistically connect the two diseases via iron. Low iron levels impair mitochondrial function (Masini et al., 1994), and increase oxidative stress markers (Knutson et al., 2000), possibly by limiting the function of the irondependent antioxidant, catalase (Wan et al., 2012a). Longer-term studies of rodent models of BID will illuminate the neuroanatomical and neurobiochemical changes that result from low iron bioavailability.

\section{IRON ACCUMULATION IN THE BRAIN}

The sophisticated mechanisms that manage iron in the brain highlight the need for tightly controlled iron regulation, in order to exploit its utility in cellular operations, while preventing its deleterious capacity. Functional loss of IRPs by genetic mutations induces brain iron deposition, which is sufficient to cause neurodegeneration in diseases like aceruloplasminemia (Miyajima et al., 1987; Hochstrasser et al., 2004) and neuroferritinopathy (Feyt et al., 2001; Chinnery et al., 2007). This demonstrates the potential for iron elevation to participate in neuronal loss of more common neurodegenerative diseases [e.g., Alzheimer's (AD) and Parkinson's disease $(\mathrm{PD})]$ where brain iron elevation features in both diseases.

\section{BRAIN IRON ACCUMULATION WITH AGING}

Aging is an important risk factor for neurodegenerative diseases. Multiple failures of the iron regulatory system in disease could be contributed to by the aging process (Bartzokis et al., 1997; Martin et al., 1998; Pfefferbaum et al., 2009; Penke et al., 2012; Daugherty and Raz, 2013). Age-related iron retention can serve as predictors of behavioral deficits, such as cognitive decline (Penke et al., 2012) and motor impairment (Cass et al., 2007; Kastman et al., 2012), highlighting the possibility of its involvement in age-associated decline.

Brain iron elevation with age could be contributed to by changes in various proteins that comprise the iron regulation machinery. Ferritin is elevated during the aging process in both gray and white matter of occipital cortex (Connor et al., 1992b) and the SN (Zecca et al., 2004), but is unchanged in motor cortex and superior temporal gyrus (Connor et al., 1992b). Tf expression was found to be decreased in white matter of superior temporal gyrus, but elevated in white matter of occipital cortex (Connor et al., 1992b). Cp was found to be elevated in gray matter with aging, without changes in white matter (Connor et al., 1993), while another report observed that $\mathrm{Cp}$ was unchanged in $\mathrm{SN}$ (Zecca et al., 2004). In rat brains, iron and ferritin were found to increase with age, while Tf levels remain unchanged (Roskams and Connor, 1994). The mechanism of age-related iron accumulation is only beginning to be elucidated. The selective vulnerability of iron accumulation during aging could also explain why iron elevation is a feature of various neurodegenerative diseases.

\section{ALZHEIMER'S DISEASE}

Alzheimer's disease is the most prevalent neurodegenerative disease characterized clinically by progressive dementia, and pathologically by the presence of $\mathrm{A} \beta$-containing plaques, and tau-containing neurofibrillary tangles in affected brain areas. Elevated iron is also a feature of $\mathrm{AD}$-effected post-mortem brains (Zhu etal., 2009; Duce et al., 2010; Smith et al., 2010; Qin et al., 2011; Antharam et al., 2012; Loef and Walach, 2012). Iron accumulation occurs in $\mathrm{AD}$ cortex and hippocampus, but not cerebellum (Andrasi et al., 1995; Duce et al., 2010; Antharam et al., 2012), consistent with the pathological profile of neurodegeneration in AD. In addition, iron is accumulated in both plaques and tangles (Connor et al., 1992a; Smith et al., 1997; Meadowcroft et al., 2009), and is estimated to be three times that of the normal neuropil level in plaques (Lovell et al., 1998). The iron content in hippocampus of patients with $\mathrm{AD}$ was reported to correlate with the mini-mental state examination (MMSE) and the disease duration (Ding et al., 2009; Zhu et al., 2009), suggesting that iron can play a significant role in the disease progression.

Several genes of iron regulatory proteins are risk factors for sporadic $\mathrm{AD}$, including $\mathrm{Tf}$ and human hemochromatosis protein (HFE). In a genome-wide association study (GWAS) study, Tf variant $\mathrm{C} 2$ positively correlates with $\mathrm{AD}$ risk with an $\mathrm{OR}$ of 1.21 (Bertram and Tanzi, 2008), which is supported by a number of independent studies (Van Landeghem et al., 1998; Schjeide et al., 2009; Kauwe et al., 2010) but was not confirmed in a recent largescale GWAS study (Hollingworth et al., 2011). In addition, HFE mutations (H63D and C82Y) are risk factors for AD independently (Sampietro et al., 2001; Blazquez et al., 2007), and synergistically with APOE gene (Kauwe et al., 2010; Giambattistelli et al., 2011; Lehmann et al., 2012). Both of the genes are also shown to modulate iron content, and are implicated in the risk of cognitive impairment in normal aging (Bartzokis et al., 2011).

Iron accumulation can promote aggregation of both $A \beta$ and tau, the key proteins involved in plaque and tangle formation, respectively. Three histidine residues of $A \beta$ were suggested as the binding amino acids of iron, and this complex is redox-active (Nakamura et al., 2007; Bousejra-ElGarah et al., 2011). Recently it was found that iron delayed the amyloid fibril formation but enhanced the toxicity in vitro, suggesting the iron-bound $\mathrm{A} \beta$ oligomer could serve as a toxic species (Mantyh et al., 1993; Schubert and Chevion, 1995; Liu et al., 2011). These observations are relevant to disease since iron is concentrated in plaques (Meadowcroft etal., 2009; Gallagher et al., 2012), and increased iron content is prior to plaque formation in an animal model of $\mathrm{AD}$ (Leskovjan etal., 2011). A $\beta$-iron complex can induce ROS via Fenton chemistry (Rottkamp et al., 2001; Rival et al., 2009), and activate B-cell lymphoma 2 (Bcl-2) apoptosis pathway (Kuperstein and Yavin, 2003). Chelation of iron can prevent A $\beta$ aggregation, and reverse the consequent memory loss in animal models of $\mathrm{AD}$ (Huang et al., 2004; Guo et al., 2013b).

Iron and tangles co-localized in AD (Smith et al., 1997) and tangles can bind iron in a redox-dependent manner, acting as a source for ROS within the neurons (Smith et al., 1997; Sayre et al., 2000). This process can also be removed by iron chelation (Shin et al., 2003). Fe(III), but not Fe(II), can induce tau aggregation in vitro, which again can be reversed by reducing $\mathrm{Fe}$ (III) to $\mathrm{Fe}$ (II) (Yamamoto et al., 2002) or iron chelators (Amit et al., 2008). Fe(II) can induce tau hyperphosphorylation (Lovell et al., 2004; Chan and Shea, 2006), via activation of extracellular signalregulated kinase $1 / 2($ Erk1/2) pathway or the mitogen-activated 
protein kinase (MAPK) pathway (Muñoz et al., 2006; Huang et al., 2007). Chelation therapies such as deferoxamine can inhibit ironinduced tau hyperphosphorylation in vivo (Guo et al., 2013a), and prevention of iron uptake can also inhibit this event by deactivating glycogen synthase kinase 3 (GSK-3) and cyclin-dependent kinase 5 (Cdk-5; Xie et al., 2012), two key tau kinases (Lei et al., 2011).

Understanding the cause of iron accumulation in $\mathrm{AD}$ might lead to new therapeutic opportunities. Multiple components of the iron regulatory system are altered in AD including IRP2 (Smith et al., 1998), ferritin (Connor et al., 1992a), and Tf (Loeffler et al., 1995). Of particular interest is APP, which is involved in A $\beta$ production and iron homeostasis. APP expression is unchanged in $\mathrm{AD}$ cortex but its ferroxidase activity was reported to be decreased (Duce et al., 2010). This could prevent ferroportin-mediated iron export and $\mathrm{Tf}$ loading, which would lead to iron retention within neurons. APP-mediated iron export is also impacted by ADassociated tau protein (Lei et al., 2012). Soluble tau levels are reduced in $\mathrm{AD}$ brains compared to control brains (Ksiezak-Reding et al., 1988; Shin et al., 1992; Khatoon et al., 1994; Zhukareva et al., 2001, 2003; van Eersel et al., 2009); which might result from tau deposition into insoluble aggregates during the disease progress (Khatoon et al., 1994). Loss of functional tau could further perturb APP-mediated iron export by restricting the presentation of $\mathrm{APP}$ at the surface.

\section{PARKINSON'S DISEASE}

Parkinson's disease is the most prevalent movement disorder, caused by loss of dopaminergic neurons in the $\mathrm{SN}$ pars compacta. The brain of PD patients, and especially the $\mathrm{SN}$, is decorated by Lewy body inclusions that are enriched with the $\alpha$-synuclein protein. As early as 1924, iron deposition in the SN of PD patients was described (Lhermitte et al., 1924). Iron elevation within this nucleus has been consistently reported using multiple techniques such as inductively coupled plasma-mass spectrometry (ICPMS; Dexter etal., 1989; Lei etal., 2012), atomic absorption spectroscopy (Ayton et al., 2012b), X-ray fluorescence (Popescu et al., 2009), and MRI (Bartzokis et al., 1999).

Iron deposits have been found in Lewy Bodies in PD cases (Castellani et al., 2000), suggesting that $\alpha$-synuclein may interact with iron at the biochemical level. Indeed, iron binds to $\alpha$-synuclein (Bharathi and Rao, 2008; Peng et al., 2010), accelerates $\alpha$-synuclein aggregation (Golts et al., 2002; Kostka et al., 2008), and causes toxic hydroxyl radical production in vitro (Turnbull et al., 2001). Treating iron to cells initiates $\alpha$-synuclein aggregation (Ostrerova-Golts et al., 2000; Gault et al., 2010; Li et al., 2011), and the resultant oligomer promoted $\alpha$-amino-3-hydroxy5-methyl-4-isoxazolepropionic acid (AMPA)-receptor-mediated excitotoxicity (Huls et al., 2011). Iron administration to cells that overexpress a disease-related mutant form of $\alpha$-synuclein, A53T, enhanced cytotoxicity of the protein via increasing the autophagic activity (Ostrerova-Golts et al., 2000; Chew et al., 2011), which could explain how iron causes toxicity in PD.

Iron content in $\mathrm{SN}$ is a risk factor and may serve as a biomarker of PD. Mutations in a number of iron-related proteins have been shown to associate with the risk of $\mathrm{PD}$, including $\mathrm{Tf}$ (Borie et al., 2002), IRP2 (Deplazes et al., 2004), ferritin (Foglieni et al., 2007), and DMT1 (He et al., 2011). It has been debated whether iron accumulation in $\mathrm{SN}$ is a secondary effect of cell death in PD. However, recent developments in MRI and transcranial sonography (TCS) makes it possible to examine brain iron content in living patients. It has been shown using MRI that iron accumulates at the early stage of PD before the symptom onset (Bartzokis et al., 1999; Martin et al., 2008), and healthy individuals with increased SN iron content determined by TCS had 17 times higher risk of developing PD (Berg etal., 2011). The SN iron elevation in PD patients, shown by MRI, correlates with the disease susceptibility (Baudrexel et al., 2010), severity (Atasoy et al., 2004; Wallis et al., 2008) and duration of the disease (Kosta et al., 2006; Zhang et al., 2010). The early rise in iron, measured by TCS and MRI supports a role for iron in the pathogenicity of PD.

Iron accumulation is alone sufficient to cause parkinsonian neurodegeneration. Direct iron injection to rat brains can cause SN neuron loss (Ben-Shachar and Youdim, 1991), and feeding neonatal mice with iron can trigger later life parkinsonism and nigral degeneration (Kaur et al., 2007). Diseases primarily characterized by brain iron accumulation, including aceruloplasminemia (Miyajima etal., 1987; Hochstrasser et al., 2004; McNeill et al., 2008), neuroferritinopathy (Crompton et al., 2002; Chinnery et al., 2007), and iron accumulation (NBIA) (Schneider et al., 2012), often cause symptoms of PD. The observations from these diseases which are caused by rare loss-of-function mutations of IRPs indicate that a similar iron accumulation observed in idiopathic PD likely participates in the degenerative processes. Aceruloplasminemia can be recapitulated in mice that lack the Cp gene, and this can be rescued with iron chelation (Patel et al., 2002; Ayton et al., 2012b).

Modulation of iron shows beneficial effects on PD animal models. PD toxin model, 1-methyl-4-phenyl-1,2,3,6tetrahydropyridine (MPTP) or 6-hydroxydopamine (6-OHDA) cause $\mathrm{SN}$ iron accumulation in mice, coincident with neuronal loss (Hare et al., 2013). These PD models can be rescued by iron chelation (Kaur et al., 2003; Mandel et al., 2004; Youdim et al., 2004a,b). Iron-mediated toxicity in these models can also be ameliorated by genetic or pharmacologically restoring ferritin (Kaur et al., 2003) and $\mathrm{Cp}$ (Ayton et al., 2012b).

Why does iron accumulate in PD? This could be contributed by a number of iron-related proteins that are changed in PD. Ferritin levels have been found to be decreased in post-mortem PD brains (Dexter et al., 1990; Werner et al., 2008); loss of iron storage capacity potentially makes free iron species more available for toxic interactions. Iron accumulation in PD might be caused by increased neuronal iron import. DMT1 is elevated in SN of PD patients (Salazar et al., 2008), which could promote iron import, but the levels of TfR1, which is required for DMT1-mediated iron import are unchanged when corrected for neuronal loss (Mash et al., 1991; Morris et al., 1994; Faucheux et al., 1997). Alternatively, iron accumulation in PD could also be attributed to reduced iron export. Cp levels in PD brains were unaltered, however, the activity is selectively reduced in $\mathrm{SN}$, which could bottleneck iron export (Ayton et al., 2012b). Tau protein is also implicated in PD (Lei et al., 2010), and selective reduction of tau found in SN of PD patients may also contribute to iron accumulation by preventing APP-mediated iron export (Lei et al., 2012). 


\section{OTHER NEUROLOGICAL DISORDERS}

Iron accumulation has been observed in affected brain regions of various diseases including progressive supranuclear palsy (Coffey et al., 1989; Dexter et al., 1991; Boelmans et al., 2012), Pick's disease (Ehmann et al., 1984), Huntington's disease (Dexter et al., 1991; Bartzokis et al., 2007; Jurgens et al., 2010; Rosas et al., 2012), prion disorders (Singh et al., 2009a, 2012), amyotrophic lateral sclerosis (Oba et al., 1993; Santillo et al., 2009; Langkammer et al., 2010), and multiple system atrophy with striatonigral degeneration (Dexter et al., 1991; Vymazal et al., 1999; von Lewinski et al., 2007; Wang et al., 2012). The iron accumulation in diseases such as prion disorders and Huntington's disease may result from ferritin accumulation (Simmons et al., 2007; Singh et al., 2012), but the cause or implications of iron elevation for these diseases is unclear at this stage.

Friedreich's ataxia is a disorder of iron metabolism more extensively studied. This autosomal recessive degenerative disease results from mutations in the mitochondrial protein frataxin (Campuzano et al., 1996; Carvajal et al., 1996). Friedreich's ataxia is characterized by degeneration of large sensory neurons and cardiomyopathy (Gordon, 2000), but brain atrophy and iron accumulation are also features of the disease (Synofzik et al., 2011). Recent studies suggested that the function of frataxin is related to the maintenance of iron homeostasis, acting as iron-storage protein in mitochondrial similar to ferritin, and also an intramitochondrial iron chaperone. It is also suggested to be involved in heme and iron sulfur cluster biogenesis. The frataxin mutant is unstable and severe reduction of the protein results in intramitochondrial iron accumulation and cytosolic iron deficiency in mice and humans, and is suggested to contribute to the pathogenesis of the disease (Gordon, 2000; Puccio et al., 2001; Richardson et al., 2010). Interestingly, a high iron diet limits some of the phenotypes in mouse models such as cardiac hypertrophy (Whitnall et al., 2012).

Like iron, copper also participates in neurodegenerative pathways. Copper is able to cause the aggregation of alpha synuclein (Bharathi and Rao, 2008), and copper is a co-factor of dopamine beta-hydroxylase, which is involved in dopamine synthesis (Ash et al., 1984). Copper is decreased in PD SN (Dexter et al., 1991; Ayton et al., 2012b) which might be a reason why the copperdependent Cp protein is dysfunctional in the disease. Peripheral Cp is also depleted in Wilson's disease, which is primarily a disorder of copper homeostasis, caused by a genetic mutation to ATP7b (Bull et al., 1993). Copper accumulates in liver and brain, along with iron (Shiono et al., 2001; Litwin et al., 2013). Why does iron also accumulate as a result of the disease? Possibly reduced Cp levels in plasma reduce iron export in liver and brain, resulting in iron accumulation. Whatever the mechanism, Wilson's disease often presents as early-onset PD, possibly mediated by the elevation of copper and iron (Machado et al., 2006).

\section{TOXICITY MECHANISMS OF IRON OVERLOAD IN DISEASES}

Iron can induce neurotoxicity by its ability to promote the formation of ROS, a source of oxidative stress. Elevated iron is potentially neurotoxic, indeed the direct injection of iron into the rat brain causes neurodegeneration (Ben-Shachar and Youdim, 1991), possibly via an oxidative stress pathway which initiates several apoptotic signaling pathways (Ke and Ming Qian, 2003).

Recently, a type of RAS-related cell death pathway was shown to be linked with intracellular iron levels, termed ferroptosis (Dixon et al., 2012), which could be potentially responsible for cell death seen in iron overload diseases. This type of cell death pathway shared no markers of apoptosis (e.g., caspase activation, mitochondrial cytochrome $\mathrm{c}$ release), but could be prevented by iron chelation or iron uptake inhibition (Yagoda et al., 2007; Yang and Stockwell, 2008). This pathway is not induced by Fenton chemistry; rather it is related with iron-dependent enzymatic activities (Dixon et al., 2012). Indeed, inappropriate intracellular iron accumulation potentially damages a number of proteins such as $\mathrm{Ca}^{2+}$-ATPase (Kaplan et al., 1997; Moreau et al., 1998), glutamate transporter (Gnana-Prakasam et al., 2009; Yu et al., 2009; Mitchell et al., 2011), $\mathrm{Na}^{+} / \mathrm{K}^{+}$-ATPase (Kaplan et al., 1997; Strugatsky et al., 2003), and $N$-methyl-D-aspartate (NMDA) receptor (Nakamichi et al., 2002; Munoz et al., 2011), as well as oxidizes lipid such as cholesterol (Kraml et al., 2005; Graham et al., 2010; Shinkyo and Guengerich, 2011), ceramides (Yurkova et al., 2005), and sphingomyelin (Jenkins and Kramer, 1988; Isaac et al., 2006); all of which were proposed to ultimately cause synaptic dysfunction and neuronal cell death (Mattson, 2004).

It is therefore not surprising that iron elevation observed in a number of neurodegenerative diseases, such as $\mathrm{AD}$ and $\mathrm{PD}$, is proposed to be a key mediator in cell loss of these diseases (Ayton et al., 2012a; Lei et al., 2012). In neurodegenerative diseases, iron is also found to partner with disease-related proteins, such as $\beta$ amyloid, tau, prion, and $\alpha$-synuclein, which form soluble and insoluble aggregates and activate cell death pathways (Chiti and Dobson, 2006). The presence of iron accelerates the aggregation process in vitro (Schubert and Chevion, 1995; Ostrerova-Golts et al., 2000; Rottkamp et al., 2001; Yamamoto et al., 2002; Khan et al., 2006), and aggravates the oxidative stress induced by the protein in vivo (Huls et al., 2011; Li et al., 2011; Wan et al., 2011).

Recently it has emerged that these disease-related proteins also participate in iron metabolism. The mRNA of APP has an IRE in its 5'-UTR (Rogers et al., 2002, 2008), and was found to facilitate iron export in vitro and in vivo (Duce et al., 2010). Suppression of APP expression in mice resulted in age-dependent iron accumulation (Duce et al., 2010), and overexpression of wild type APP resulted in iron reduction in SH-SY5Y neuroblastoma cells (Wan et al., 2012b). Interestingly, overexpression of a diseaserelated mutant form of APP, the Swedish mutant, in SH-SY5Y cells and Caenorhabditis elegans causes significant iron retention accompanied with elevated ROS (Wan et al., 2011). It was proposed by the authors that the observed iron change is due to the increased amount of $A \beta$ (Wan et al., 2011), however, it can be alternatively explained by loss-of-APP function. A $\beta$ oligomers were shown to decrease NTBI uptake, however, the disease relevance was unclear (SanMartin et al., 2012). Recently, tau protein was found to mediate APP trafficking, and reduction of tau blocked iron export, leading to intracellular iron accumulation (Lei et al., 2012). Tau knockout mice exhibited age-dependent neurodegeneration, which could be pharmacologically prevented by iron chelation therapy (Lei etal., 2012), supporting a function of tau in iron metabolism. 
Other disease related proteins have been investigated less for their association with iron metabolism, but the emerging data could point to a role for these proteins in iron homeostasis. $\alpha$ synuclein exhibits an IRE in its $5^{\prime}$-UTR mRNA (Friedlich et al., 2007), and is reported to be ferrireductase of unknown biological function (Davies et al., 2011). Recently, prion protein was also suggested to act as a functional ferrireductase, to modulate cellular iron uptake (Singh et al., 2009c, 2013). Loss of prion protein caused iron deficiency in mice, which can be reversed by expression of wild type prion protein (Singh et al., 2009b). In addition, huntingtin protein, involved in Huntington's disease, was also reported as an iron-responsive protein (Hilditch-Maguire et al., 2000). In huntingtin-deficient zebrafish, iron starvation was identified during development, and these zebrafish had decreased hemoglobin production (Lumsden et al., 2007).

\section{THERAPEUTICS BASED ON IRON MODULATION}

Since iron involves the pathogenesis of neurodegenerative disorders, chelation of iron therefore could be a therapeutic strategy. Currently, iron chelation is utilized in practice for transfusional iron overload and hemochromatosis (Nick, 2007). Treatment for this type of diseases requires selective iron chelators with high affinity, to facilitate bulk excretion of iron from the body (Positano et al., 2009; Meloni et al., 2010; Murphy and Oudit, 2010; Pietrangelo, 2010). Deferoxamine (Propper et al., 1976), deferiprone (Kontoghiorghes et al., 1987a,b) and deferasirox (Piga et al., 2006; Shashaty et al., 2006) have been tested for these diseases. However, neurodegenerative diseases that feature regional iron accumulation require therapeutic agents to cross blood-brain barrier, and target specific brain regions in preference to the rest of the body.

Several brain permeable iron chelators have been explored in pre-clinical models of AD and PD (Kontoghiorghes et al., 1987a; Ben-Shachar et al., 1992; Kaur et al., 2003; Youdim et al., 2004a; Liang etal., 2008; Gogoi etal., 2011) although none of these compounds have entered clinical trials so far. One pilot trial of deferiprone was reported to be beneficial for NBIA (Abbruzzese et al., 2011). The mechanisms for neuroprotection effects of iron chelators have been linked with suppression of apoptotic pathway (Youdim etal., 2005; Avramovich-Tirosh et al., 2007; Zhu et al., 2007; Amit et al., 2008; Gal et al., 2010), promoting survival pathways (Avramovich-Tirosh et al., 2010; Reznichenko et al., 2010), restoration of protein degradation (Zhu et al., 2007), and stabilization of mitochondrial function (Youdim et al., 2005).

\section{REFERENCES}

Abbott, N. J., Rönnbäck, L., and Hansson, E. (2006). Astrocyte-endothelial interactions at the blood-brain barrier. Nat. Rev. Neurosci. 7, 41-53.

Abboud, S., and Haile, D. J. (2000). A novel mammalian iron-regulated protein involved in intracellular iron metabolism. J. Biol. Chem. 275, 19906-19912. doi: 10.1074/jbc. M000713200

Abbruzzese, G., Cossu, G., Balocco, M., Marchese, R., Murgia, D., Melis, M., etal. (2011). A pilot trial of

Clioquinol is a moderate affinity iron chelator that has undergone extensive pre-clinical testing for neurodegenerative disorders, and a clinical trial (Cherny et al., 2001; Kaur et al., 2003; Ritchie et al., 2003; Lei et al., 2012). The therapeutic effects of clioquinol have often been attributed to its ionophore activity, which redistributes copper and zinc into the cell (Cherny et al., 2001; Nitzan et al., 2003; Adlard et al., 2008; Li et al., 2010; Crouch et al., 2011; Park et al., 2011). However, its ability to chelate iron is also likely involved in its neuroprotective properties. Iron binds to clioquinol (Tamura et al., 1973; Kidani et al., 1974; Ohtsuka et al., 1982), and several beneficial effects of clioquinol have reported to be iron-dependent (Felkai et al., 1999; Atamna and Frey, 2004; Choi et al., 2006; Rival et al., 2009). Treatment with clioquinol prevents the elevation of SN iron levels in MPTP-treated mice, which confers neuroprotection (Kaur et al., 2003). Similar treatment also prevented age-related nigra degeneration in tau knockout mice (Lei et al., 2012), highlighting a potential use of clioquinol as an iron-binding agent. These results suggest that clioquinol participates in iron redistribution, but more data is needed to confirm.

\section{CONCLUSION}

The tightly regulated nature of iron in the human brain protects against diseases associated with excess or deficiency. Disease manifests when these systems deteriorate or are overwhelmed. Iron deficiency is prevalent, particularly in underdeveloped societies, and causes long-term consequences to brain health. There is therefore urgent need to address nutritional deficiency in pregnancy and in infancy to prevent these long-term consequences. Iron elevation in the brain is a feature of several major neurodegenerative disorders. While the cause of this is unknown, it is noteworthy that a variety of neurodegenerative disease-associated proteins involved in iron metabolism through various mechanisms, supporting the hypothesis that iron and disease-related proteins participate in a toxic cycle. The involvement of iron in neurodegenerative diseases needs further elucidation, but iron overload in these disorders represents an attractive pharmacological target for disease modifying therapies.

\section{ACKNOWLEDGMENTS}

Supported by funds from the Australian National Health and Medical Research Council (NHMRC), Australia Research Council (ARC), Alzheimer's Australia Dementia Research Foundation, and Operational Infrastructure Support Victorian State Government.

Int. J. Biochem. Cell Biol. 33, 940959. doi: 10.1016/S1357-2725(01) 00063-2

Aisen, P. (2004). Transferrin receptor 1. Int. J. Biochem. Cell Biol. 36, 2137-2143. doi: 10.1016/j.biocel. 2004.02.007

Algarin, C., Peirano, P., Garrido, M., Pizarro, F., and Lozoff, B. (2003). Iron deficiency anemia in infancy: long-lasting effects on auditory and visual system functioning. Pediatr. Res. 53, 217-223. doi: 10.1203/01. PDR.0000047657.23156.55
Allen, R. P., Barker, P. B., Wehrl, F., Song, H. K., and Earley, C. J. (2001). MRI measurement of brain iron in patients with restless legs syndrome. Neurology 56, 263-265. doi: 10.1212/WNL.56.2.263

Amit, T., Avramovich-Tirosh, Y., Youdim, M. B. H., and Mandel, S. (2008). Targeting multiple Alzheimer's disease etiologies with multimodal neuroprotective and neurorestorative iron chelators. FASEB J. 22, 1296-1305. doi: 10.1096/fj.07-8627rev 
Anderson, B. F., Baker, H. M., Dodson, E. J., Norris, G. E., Rumball, S. V., Waters, J. M., etal. (1987). Structure of human lactoferrin at 3.2-A resolution. Proc. Natl. Acad. Sci. U.S.A. 84, 1769-1773. doi: 10.1073/pnas.84.7.1769

Andrasi, E., Farkas, E., Scheibler, H., Reffy, A., and Bezur, L. (1995). Al, $\mathrm{Zn}, \mathrm{Cu}, \mathrm{Mn}$ and Fe levels in brain in Alzheimer's disease. Arch. Gerontol. Geriatr. 21, 89-97.

Antharam, V., Collingwood, J. F., Bullivant, J. P., Davidson, M. R., Chandra, S., Mikhaylova, A., et al. (2012). High field magnetic resonance microscopy of the human hippocampus in Alzheimer's disease: quantitative imaging and correlation with iron. NeuroImage 59, 1249-1260. doi: 10.1016/j.neuroimage.2011.08.019

Armony-Sivan, R., Eidelman, A. I., Lanir, A., Sredni, D., and Yehuda, S. (2004). Iron status and neurobehavioral development of premature infants. J. Perinatol. 24, 757-762. doi: 10.1038/s.jp.j211178

Ash, D. E., Papadopoulos, N. J., Colombo, G., and Villafranca, J. J. (1984). Kinetic and spectroscopic studies of the interaction of copper with dopamine beta-hydroxylase. $J$. Biol. Chem. 259, 3395-3398.

Atamna, H., and Frey, W. H. (2004). A role for heme in Alzheimer's disease: heme binds amyloid beta and has altered metabolism. Proc. Natl. Acad. Sci. U.S.A. 101, 11153-11158. doi: 10.1073/pnas.0404349101

Atasoy, H. T., Nuyan, O., Tunc, T., Yorubulut, M., Unal, A. E., and Inan, L. E. (2004). T2-weighted MRI in Parkinson's disease; substantia nigra pars compacta hypointensity correlates with the clinical scores. Neurol. India 52, 332-337.

Avramovich-Tirosh, Y., Bar-Am, O., Amit, T., Youdim, M. B., and Weinreb, O. (2010). Up-regulation of hypoxiainducible factor (HIF)-1alpha and HIF-target genes in cortical neurons by the novel multifunctional iron chelator anti-Alzheimer drug, M30. Curr. Alzheimer Res. 7, 300-306. doi: 10.2174/156720510791162403

Avramovich-Tirosh, Y., Reznichenko, L., Mit, T., Zheng, H., Fridkin, M., Weinreb, O., et al. (2007). Neurorescue activity, APP regulation and amyloid-beta peptide reduction by novel multi-functional brain permeable iron- chelating- antioxidants, $\mathrm{M}$ 30 and green tea polyphenol, EGCG. Curr. Alzheimer Res. 4, 403-411. doi: 10.2174/156720507781788927

Ayton, S., Lei, P., and Bush, A. I. (2012a). Metallostasis in Alzheimer's disease. Free Radic. Biol.
Med. doi: 10.1016/j.freeradbiomed. 2012.10.558 [Epub ahead of print].

Ayton, S., Lei, P., Duce, J. A., Wong, B. X., Sedjahtera, A., Adlard, P. A. et al. (2012b). Ceruloplasmin dysfunction and therapeutic potential for parkinson disease. Ann Neurol. doi: 10.1002/ana.23817 [Epub ahead of print].

Bartzokis, G., Beckson, M., Hance, D. B., Marx, P., Foster, J. A., and Marder, S. R. (1997). MR evaluation of agerelated increase of brain iron in young adult and older normal males. Magn. Reson. Imaging 15, 29-35. doi: 10.1016/S0730-725X(96)00234-2

Bartzokis, G., Cummings, J. L., Markham, C. H., Marmarelis, P. Z., Treciokas, L. J., Tishler, T. A., et al. (1999). MRI evaluation of brain iron in earlier- and later-onset Parkinson's disease and normal subjects. Magn Reson. Imaging 17, 213-222. doi: 10.1016/S0730-725X(98)00155-6

Bartzokis, G., Lu, P. H., Tingus, K., Peters, D. G., Amar, C. P., Tishler, T. A., etal. (2011). Gender and iron genes may modify associations between brain iron and memory in healthy aging. Neuropsychopharmacology $36,1375-1384$. doi: 10.1038/npp.2011.22

Bartzokis, G., Lu, P. H., Tishler, T. A., Fong, S. M., Oluwadara, B., Finn, J. P., et al. (2007). Myelin breakdown and iron changes in Huntington's disease: pathogenesis and treatment implications. Neurochem. Res. 32, 1655 1664. doi: 10.1007/s11064-0079352-7

Baudrexel, S., Nurnberger, L., Rub, U., Seifried, C., Klein, J. C., Deller, T., etal. (2010). Quantitative mapping of $\mathrm{T} 1$ and $\mathrm{T} 2^{*}$ discloses nigral and brainstem pathology in early Parkinson's disease. Neuroimage 51, 512-520. doi: $10.1016 /$ j.neuroimage.2010.03.005

Beard, J. L. (2001). Iron biology in immune function, muscle metabolism and neuronal functioning. J. Nutr. 131, 568S-579S; discussion $580 \mathrm{~S}$.

Beard, J. L., Chen, Q., Connor, J., and Jones, B. C. (1994). Altered monamine metabolism in caudateputamen of iron-deficient rats. Pharmacol. Biochem. Behav. 48, 621624. doi: 10.1016/0091-3057(94) 90323-9

Beard, J. L., Felt, B., Schallert, T., Burhans, M., Connor, J. R., and Georgieff, M. K. (2006a). Moderate iron deficiency in infancy: biology and behavior in young rats. Behav. Brain Res. 170, 224-232. doi: 10.1016/j.bbr.2006.02.024
Beard, J. L., Wiesinger, J. A., and Jones, B. C. (2006b). Cellular iron concentrations directly affect the expression levels of norepinephrine transporter in PC12 cells and rat brain tissue. Brain Res. 1092, 47-58. doi: 10.1016/j.brainres.2006.03.071

Benkovic, S. A., and Connor, J. R. (1993). Ferritin, transferrin, and iron in selected regions of the adult and aged rat brain. J. Comp. Neurol. 338, 97-113. doi: 10.1002/cne.903380108

Ben-Shachar, D., Ashkenazi, R., and Youdim, M. B. (1986). Long-term consequence of early iron-deficiency on dopaminergic neurotransmission in rats. Int. J. Dev. Neurosci. 4 81-88. doi: 10.1016/0736-5748(86) 90019-5

Ben-Shachar, D., Eshel, G., Riederer, P., and Youdim, M. B. (1992) Role of iron and iron chelation in dopaminergic-induced neurodegeneration: implication for Parkinson's disease. Ann. Neurol. 32(Suppl.), S105-S110. doi: 10.1002/ana. 410320718

Ben-Shachar, D., and Youdim, M. B. H. (1991). Intranigral iron injection induces behavioral and biochemical "parkinsonism" in rats. J. Neurochem. 57, 2133-2135. doi: 10.1111/j.1471 4159.1991.tb06432.x

Berg, D., Seppi, K., Behnke, S., Liepelt, I., Schweitzer, K., Stockner, H., et al. (2011). Enlarged substantia nigra hyperechogenicity and risk for Parkinson disease: a 37-month 3-center study of 1847 older persons. Arch. Neurol. 68, 932-937. doi: 10.1001/archneurol.2011.141

Bertram, L., and Tanzi, R. E. (2008). Thirty years of Alzheimer's disease genetics: the implications of systematic meta-analyses. Nat. Rev. Neurosci. 9, 768-778. doi: 10.1038/nrn2494

Bharathi, and Rao, K. S. (2008). Molecular understanding of copper and iron interaction with alpha-synuclein by fluorescence analysis. J. Mol. Neurosci. 35, 273-281.

Bianco, L. E., Wiesinger, J., Earley, C. J., Jones, B. C., and Beard, J. L. (2008). Iron deficiency alters dopamine uptake and response to LDOPA injection in Sprague-Dawley rats. J. Neurochem. 106, 205-215. doi: 10.1111/j.1471-4159.2008.05358.x

Blazquez, L., De Juan, D., RuizMartinez, J., Emparanza, J. I., Saenz A., Otaegui, D., et al. (2007). Genes related to iron metabolism and susceptibility to Alzheimer's disease in Basque population. Neurobiol. Aging 28, 1941-1943.

Boelmans, K., Holst, B., Hackius, M. Finsterbusch, J., Gerloff, C., Fiehler,
J., et al. (2012). Brain iron deposition fingerprints in Parkinson's disease and progressive supranuclear palsy. Mov. Disord. 27, 421-427. doi: 10.1002/mds. 24926

Borie, C., Gasparini, F., Verpillat, P., Bonnet, A. M., Agid, Y., Hetet, G., et al. (2002). Association study between iron-related genes polymorphisms and Parkinson's disease. J. Neurol. 249, 801-804. doi: 10.1007/s00415-002-0704-6

Bousejra-ElGarah, F., Bijani, C., Coppel, Y., Faller, P., and Hureau, C. (2011). Iron(II) binding to amyloid-beta, the Alzheimer's peptide. Inorg. Chem. 50, 9024-9030. doi: 10.1021/ic201233b

Bradbury, M. W. (1997). Transport of iron in the blood-braincerebrospinal fluid system. J. Neurochem. 69, 443-454. doi: 10.1046/ j.1471-4159.1997.69020443.x

Breuer, W., Hershko, C., and Cabantchik, Z. I. (2000). The importance of non-transferrin bound iron in disorders of iron metabolism. Transfus. Sci. 23, 185-192. doi: 10.1016/S0955-3886(00)00087-4

Bull, P. C., Thomas, G. R., Rommens, J. M., Forbes, J. R., and Cox, D. W. (1993). The Wilson disease gene is a putative copper transporting Ptype ATPase similar to the Menkes gene. Nat. Genet. 5, 327-337. doi: $10.1038 /$ ng1293-327

Burdo, J. R., Menzies, S. L., Simpson, I. A., Garrick, L. M., Garrick, M. D., Dolan, K. G., et al. (2001). Distribution of divalent metal transporter 1 and metal transport protein 1 in the normal and Belgrade rat. $J$. Neurochem. 66, 1198-1207.

Burhans, M., Dailey, C., Beard, Z., Wiesinger, J., Murray-Kolb, L., Jones, B., et al. (2005). Iron deficiency: differential effects on monoamine transporters. Nutr. Neurosci. 8, 31-38. doi: 10.1080/10284150500047070

Camaschella, C., Roetto, A., Calì, A., De Gobbi, M., Garozzo, G., Carella, M., et al. (2000). The gene TFR2 is mutated in a new type of haemochromatosis mapping to 7q22. Nat. Genet. 25, 14-15.

Campuzano, V., Montermini, L., Molto, M. D., Pianese, L., Cossee, M., Cavalcanti, F., et al. (1996). Friedreich's ataxia: autosomal recessive disease caused by an intronic GAA triplet repeat expansion. Science 271, 1423-1427. doi: 10.1126/science.271.5254.1423

Carvajal, J. J., Pook, M. A., Dos Santos, M., Doudney, K., Hillermann, R., Minogue, S., et al. (1996). The Friedreich's ataxia gene encodes a novel phosphatidylinositol-4phosphate 5-kinase. Nat. Genet. 
14, 157-162. doi: 10.1038/ng1096157

Cass, W. A., Grondin, R., Andersen, A. H., Zhang, Z., Hardy, P. A., Hussey-Andersen, L. K., et al. (2007). Iron accumulation in the striatum predicts aging-related decline in motor function in rhesus monkeys. Neurobiol. Aging 28, 258-271. doi: 10.1016/j.neurobiolaging.2005. 12.010

Castellani, R. J., Siedlak, S. L., Perry, G., and Smith, M. A. (2000). Sequestration of iron by Lewy bodies in Parkinson's disease. Acta Neuropathol. 100, 111-114. doi: 10.1007/ s004010050001

Chan, A., and Shea, T. B. (2006). Dietary and genetically-induced oxidative stress alter tau phosphorylation: influence of folate and apolipoprotein E deficiency. J. Alzheimers Dis. 9, 399-405.

Chen, J.-H., Shahnavas, S., Singh, N. N., Ong, W.-Y., and Walczyk, T. (2013). Stable iron isotope tracing reveals significant brain iron uptake in the adult rat. Metallomics. 5, 167-173. doi: $10.1039 / \mathrm{c} 2 \mathrm{mt} 20226 \mathrm{c}$

Cherny, R. A., Atwood, C. S., Xilinas, M. E., Gray, D. N., Jones, W. D., Mclean, C. A., et al. (2001). Treatment with a copper-zinc chelator markedly and rapidly inhibits beta-amyloid accumulation in Alzheimer's disease transgenic mice. Neuron 30, 665676. doi: 10.1016/S0896-6273(01) 00317-8

Chew, K. C., Ang, E. T., Tai, Y. K., Tsang, F., Lo, S. Q., Ong, E., et al. (2011). Enhanced autophagy from chronic toxicity of iron and mutant A53T alphasynuclein: implications for neuronal cell death in Parkinson disease. J. Biol. Chem. 286, 33380-33389. doi: 10.1074/jbc.M111.268409

Chinnery, P. F., Crompton, D. E., Birchall, D., Jackson, M. J., Coulthard, A., Lombes, A., et al. (2007). Clinical features and natural history of neuroferritinopathy caused by the FTL1 460InsA mutation. Brain 130, 110 119. doi: 10.1093/brain/awl319

Chiti, F., and Dobson, C. M. (2006). Protein misfolding, functional amyloid, and human disease. Annu. Rev. Biochem. 75, 333-366. doi: 10. 1146/annurev.biochem.75.101304. 123901

Choi, S. M., Choi, K. O., Park, Y. K., Cho, H., Yang, E. G., and Park, H. (2006). Clioquinol, a $\mathrm{Cu}(\mathrm{II}) / \mathrm{Zn}$ (II) chelator, inhibits both ubiquitination and asparagine hydroxylation of hypoxia-inducible factor-1alpha, leading to expression of vascular endothelial growth factor and erythropoietin in normoxic cells. J. Biol. Chem. 281, 34056-34063. doi: 10.1074/jbc.M603913200

Clardy, S. L., Earley, C. J., Allen, R. P., Beard, J. L., and Connor, J. R. (2006). Ferritin subunits in CSF are decreased in restless legs syndrome. J. Lab. Clin. Med. 147, 67-73. doi: 10.1016/j.lab.2005.06.011

Coffey, C. E., Alston, S., Heinz, E. R., and Burger, P. C. (1989). Brain iron in progressive supranuclear palsy: clini$\mathrm{cal}$, magnetic resonance imaging, and neuropathological findings. J. Neuropsychiatry Clin. Neurosci. 1, 400 404.

Connor, J. R., Boyer, P. J., Menzies, S. L., Dellinger, B., Allen, R. P., Ondo, W. G., et al. (2003). Neuropathological examination suggests impaired brain iron acquisition in restless legs syndrome. Neurology 61, 304-309. doi: 10.1212/01.WNL.0000078887.16593.12

Connor, J. R., and Menzies, S. L. (1998). Relationship of iron to oligondendrocytes and myelination. Glia 17, 83-93. doi: 10.1002/(SICI)10981136(199606)17:2

Connor, J. R., Menzies, S. L., St Martin, S. M., and Mufson, E. J. (1992a). A histochemical study of iron, transferrin, and ferritin in Alzheimer's diseased brains. J. Neurosci. Res. 31 75-83. doi: 10.1002/jnr.490310111

Connor, J. R., Snyder, B. S., Beard, J. L., Fine, R. E., and Mufson, E. J. (1992b). Regional distribution of iron and iron-regulatory proteins in the brain in aging and Alzheimer's disease. J. Neurosci. Res. 31, 327-335. doi: 10.1002/jnr.490310214

Connor, J. R., Snyder, B. S., Beard, J. L., Fine, R. E., and Mufson, E. J. (1992c). Regional distribution of iron and iron-regulatory proteins in the brain in aging and Alzheimer's disease. J. Neurosci. Res. 31, 327-335. doi: 10.1002/jnr.490310214

Connor, J. R., Pavlick, G., Karli, D., Menzies, S. L., and Palmer, C. (1995). A histochemical study of iron-positive cells in the developing rat brain. $J$. Comp. Neurol. 355, 111-123. doi: 10.1002/cne.903550112

Connor, J. R., Tucker, P., Johnson, M., and Snyder, B. (1993). Ceruloplasmin levels in the human superior temporal gyrus in aging and Alzheimer's disease. Neurosci. Lett. 159, 88-90. doi: 10.1016/0304-3940(93)90805-U

Cortese, S., Azoulay, R., Castellanos, F. X., Chalard, F., Lecendreux, M., Chechin, D., et al. (2012). Brain iron levels in attentiondeficit/hyperactivity disorder: a pilot MRI study. World J. Biol. Psychiatry 13, 223-231. doi: 10.3109/ 15622975.2011 .570376
Cortese, S., Konofal, E., Bernardina, B. D., Mouren, M. C., and Lecendreux, M. (2009). Sleep disturbances and serum ferritin levels in children with attention-deficit/hyperactivity disorder. Eur. Child Adolesc. Psychiatry 18, 393-399. doi: 10.1007/s00787-0090746-8

Crichton, R. R., Dexter, D. T., and Ward, R. J. (2011). Brain iron metabolism and its perturbation in neurological diseases. Monatsh. Chem. 142, 341-355.

Crichton, R. R., and Ward, R. J. (1992). Iron metabolism-new perspectives in view. Biochemistry 31, 11255-11264. doi: 10.1021/bi00161a001

Crompton, D. E., Chinnery, P. F., Fey, C., Curtis, A. R., Morris, C. M., Kierstan, J., et al. (2002). Neuroferritinopathy: a window on the role of iron in neurodegeneration. Blood Cells Mol. Dis. 29, 522-531. doi: 10.1006/bcmd.2002.0589

Crouch, P. J., Savva, M. S., Hung, L. W., Donnelly, P. S., Mot, A. I., Parker, S. J., et al. (2011). The Alzheimer's therapeutic PBT2 promotes amyloid-beta degradation and GSK3 phosphorylation via a metal chaperone activity. J. Neurochem. 119, 220-230. doi: 10.1111/j.1471-4159.2011.07402.x

Dallman, P. R., Siimes, M. A., and Manies, E. C. (1975). Brain iron: persistent deficiency following shortterm iron deprivation in the young rat. Br. J. Haematol. 31, 209-215. doi: 10.1111/j.1365-2141.1975.tb00851.x

Dallman, P. R., and Spirito, R. A. (1977). Brain iron in the rat: extremely slow turnover in normal rats may explain long-lasting effects of early iron deficiency. J. Nutr. 107, 1075-1081.

Daugherty, A., and Raz, N. (2013). Age-related differences in iron content of subcortical nuclei observed in vivo: a meta-analysis. Neuroimage 70, 113-121. doi: 10.1016/j.neuroimage.2012.12.040

Dautry-Varsat, A., Ciechanover, A., and Lodish, H. F. (1983). pH and the recycling of transferrin during receptormediated endocytosis. Proc. Natl. Acad. Sci. U.S.A. 80, 2258-2262. doi: 10.1073/pnas.80.8.2258

Davies, P., Moualla, D., and Brown, D. R. (2011). Alpha-synuclein is a cellular ferrireductase. PLoS ONE 6:e15814. doi: 10.1371/journal.pone. 0015814

de Arriba Zerpa, G. A., Saleh, M. C., Fernández, P. M., Guillou, F., Espinosa De Los Monteros, A., De Vellis, J., et al. (2000). Alternative splicing prevents transferrin secretion during differentiation of a human oligodendrocyte cell line. J. Neurosci. Res. 61, 388-395.
De Domenico, I., Ward, D. M. V., and Kaplan, J. (2008). Regulation of iron acquisition and storage: consequences for iron-linked disorders. Nat. Rev. Mol. Cell Biol. 9, 72-81. doi: 10.1038/nrm2295

Deplazes, J., Schobel, K., Hochstrasser, H., Bauer, P., Walter, U., Behnke, S., et al. (2004). Screening for mutations of the IRP2 gene in Parkinson's disease patients with hyperechogenicity of the substantia nigra. J. Neural Transm. 111, 515-521. doi: 10.1007/s00702-004-0125-Z

Dexter, D. T., Carayon, A., Javoy-Agid, F., Agid, Y., Wells, F. R., Daniel, S. E., et al. (1991). Alterations in the levels of iron, ferritin and other trace metals in Parkinson's disease and other neurodegenerative diseases affecting the basal ganglia. Brain 114(Pt 4), 1953-1975. doi: 10.1093/brain/114. 4.1953

Dexter, D. T., Carayon, A., Vidailhet, M., Ruberg, M., Agid, F., Agid, Y., et al. (1990). Decreased ferritin levels in brain in Parkinson's disease. J. Neurochem. 55, 16-20. doi: 10.1111/j.1471-4159.1990.tb08814.x

Dexter, D. T., Wells, F. R., Lees, A. J., Agid, F., Agid, Y., Jenner, P., et al. (1989). Increased nigral iron content and alterations in other metal ions occurring in brain in Parkinson's disease. J. Neurochem. 52, 1830-1836. doi: 10.1111/j.14714159.1989.tb07264.x

Dickman, S. R., and Cloutier, A. A. (1950). Activation and stabilization of aconitase by ferrous ions. Arch. Biochem. 25, 229-231.

Ding, B., Chen, K. M., Ling, H. W., Sun, F., Li, X., Wan, T., et al. (2009). Correlation of iron in the hippocampus with MMSE in patients with Alzheimer's disease. J. Magn. Reson. Imaging 29, 793-798. doi: 10.1002/jmri.21730

Dixon, S. J., Lemberg, K. M., Lamprecht, M. R., Skouta, R., Zaitsev, E. M., Gleason, C. E., et al. (2012). Ferroptosis: an iron-dependent form of nonapoptotic cell death. Cell 149, 1060-1072. doi: 10.1016/j.cell.2012.03.042

Donfrancesco, R., Parisi, P., Vanacore, N., Martines, F., Sargentini, V., and Cortese, S. (2012). Iron and ADHD: time to move beyond serum ferritin levels. J. Atten. Disord. 17, 347-357. doi: 10.1177/1087054711430712

Donovan, A., Lima, C. A., Pinkus, J. L., Pinkus, G. S., Zon, L. I., Robine, S., et al. (2005). The iron exporter ferroportin/Slc40al is essential for iron homeostasis. Cell Metab. 1, 191-200. doi: 10.1016/j.cmet.2005.01.003

Dringen, R., Bishop, G. M., Koeppe, M., Dang, T. N., and Robinson, S. 
R. (2007). The pivotal role of astrocytes in the metabolism of iron in the brain. Neurochem. Res. 32, 1884 1890. doi: 10.1007/s11064-0079375-0

Duce, J. A., Tsatsanis, A., Cater, M. A., James, S. A., Robb, E., Wikhe, K., et al. (2010). Iron-export ferroxidase activity of $\beta$-amyloid precursor protein is inhibited by zinc in Alzheimer's disease. Cell 142, 857867. doi: 10.1016/j.cell.2010.08.014

Earley, C. J. (2003). Clinical practice. Restless legs syndrome. $N$. Engl. J. Med. 348, 2103-2109. doi: 10.1056/NEJMcp021288

Earley, C. J., Barker, P. B.Horska, A., and Allen, R. P. (2006). MRI-determined regional brain iron concentrations in early- and late-onset restless legs syndrome. Sleep Med. 7, 458-461. doi: 10.1016/j.sleep.2005.11.009

Earley, C. J., Connor, J. R., Beard, J. L., Malecki, E. A., Epstein, D. K., and Allen, R. P. (2000). Abnormalities in CSF concentrations of ferritin and transferrin in restless legs syndrome. Neurology 54, 1698-1700. doi: 10.1212/WNL.54.8.1698

Ehmann, W. D., Alauddin, M., Hossain, T. I., and Markesbery, W. R. (1984). Brain trace elements in Pick's disease. Ann. Neurol. 15, 102-104. doi: 10.1002/ana.410150119

Elia, J., and Devoto, M. (2007). ADHD genetics: 2007 update. Curr. Psychiatry Rep. 9, 434-439. doi: 10.1007/s11920-007-0057-z

Faucheux, B. A., Hauw, J. J., Agid, Y., and Hirsch, E. C. (1997). The density of [125I]-transferrin binding sites on perikarya of melanized neurons of the substantia nigra is decreased in Parkinson's disease. Brain Res. 749, 170-174. doi: 10.1016/S00068993(96)01412-6

Felkai, S., Ewbank, J. J., Lemieux, J., Labbe, J. C., Brown, G. G., and Hekimi, S. (1999). CLK-1 controls respiration, behavior and aging in the nematode Caenorhabditis elegans. EMBO J. 18, 1783-1792. doi: 10.1093/emboj/18.7.1783

Feyt, C., Morris, C. M., Bindoff, L. A., Ince, P. G., Chinnery, P. F., Coulthard, A., et al. (2001). Mutation in the gene encoding ferritin light polypeptide causes dominant adult-onset basal ganglia disease. Nat. Genet. 28, 350354. doi: 10.1038/ng571

Finch, C. A., and Huebers, H. (1982). Perspectives in iron metabolism. N. Engl. J. Med. 306, 1520-1528. doi: 10.1056/NEJM198206243062504

Fishman, J. B., Rubin, J. B., Handrahan, J. V., Connor, J. R., and Fine, R. E. (1987). Receptormediated transcytosis of transferrin across the blood-brain barrier. $J$. Neurosci. Res. 18, 299-304. doi: 10.1002/jnr.490180206

Fleming, R. E., Migas, M. C., Holden, C. C., Waheed, A., Britton, R. S., Tomatsu, S., et al. (2000). Transferrin receptor 2: continued expression in mouse liver in the face of iron overload and in hereditary hemochromatosis. Proc. Natl. Acad. Sci. U.S.A. 97, 2214-2219. doi: 10.1073/pnas.040548097

Foglieni, B., Ferrari, F., Goldwurm, S., Santambrogio, P., Castiglioni, E., Sessa, M., et al. (2007). Analysis of ferritin genes in Parkinson disease. Clin. Chem. Lab. Med. 45, 1450-1456. doi: 10.1515/CCLM.2007.307

Friedlich, A. L., Tanzi, R. E., and Rogers, J. T. (2007). The $5^{\prime}$-untranslated region of Parkinson's disease alphasynuclein messengerRNA contains a predicted iron responsive element. Mol. Psychiatry 12, 222-223. doi: 10.1038/sj.mp.4001937

Gal, S., Zheng, H., Fridkin, M., and Youdim, M. B. (2010). Restoration of nigrostriatal dopamine neurons in post-MPTP treatment by the novel multifunctional brainpermeable iron chelator-monoamine oxidase inhibitor drug, M30. Neurotox. Res. 17, 15-27. doi: 10.1007/ s12640-009-9070-9

Gallagher, J. J., Finnegan, M. E., Grehan, B., Dobson, J., Collingwood, J. F., and Lynch, M. A. (2012). Modest amyloid deposition is associated with iron dysregulation, microglial activation, and oxidative stress. J. Alzheimers Dis. 28, 147-161.

Ganz, T. (2005). Cellular iron: ferroportin is the only way out. Cell Metab. 1, 155-157. doi: 10.1016/ j.cmet.2005.02.005

Gault, N., Sandre, C., Poncy, J. L., Moulin, C., Lefaix, J. L., and Bresson, C. (2010). Cobalt toxicity: chemi$\mathrm{cal}$ and radiological combined effects on HaCaT keratinocyte cell line. Toxicol. In Vitro. 24, 92-98. doi: 10.1016/j.tiv.2009.08.027

Gerlach, M., Ben-Shachar, D., Riederer, P., and Youdim, M. B. H. (1994). Altered brain metabolism of iron as a cause of neurodegenerative diseases? J. Neurochem. 63, 793-807. doi: 10.1046/j.14714159.1994.63030793.x

Giambattistelli, F., Bucossi, S., Salustri, C., Panetta, V., Mariani, S., Siotto, M., et al. (2011). Effects of hemochromatosis and transferrin gene mutations on iron dyshomeostasis, liver dysfunction and on the risk of Alzheimer's disease. Neurobiol. Aging 33, 1633-1641. doi: 10.1016/j.neurobiolaging.2011.03.005
Gnana-Prakasam, J. P., Thangaraju, M. Liu, K., Ha, Y., Martin, P. M. Smith, S. B., et al. (2009). Absence of iron-regulatory protein Hfe results in hyperproliferation of retinal pigment epithelium: role of cystine/glutamate exchanger. Biochem. J. 424, 243-252. doi: 10.1042/BJ20090424

Gogoi, S., Antonio, T., Rajagopalan, S., Reith, M., Andersen, J., and Dutta, A. K. (2011). Dopamine $\mathrm{D}_{2} / \mathrm{D}_{3}$ agonists with potent iron chelation, antioxidant and neuroprotective properties: potential implication in symptomatic and neuroprotective treatment of Parkinson's disease. ChemMedChem 6, 991-995. doi: 10.1002/cmdc.201100140

Golts, N., Snyder, H., Frasier, M., Theisler, C., Choi, P., and Wolozin, B. (2002). Magnesium inhibits spontaneous and iron-induced aggregation of alpha-synuclein. J. Biol. Chem. 277, 16116-16123. doi: 10.1074/jbc.M107866200

Gordon, N. (2000). Friedreich's ataxia and iron metabolism. Brain Dev. 22 , 465-468. doi: 10.1016/S03877604(00)00175-3

Gottschall, D. W., Dietrich, R. F., Benkovic, S. J., and Shiman, R. (1982). Phenylalanine hydroxylase. Correlation of the iron content with activity and the preparation and reconstitution of the apoenzyme. $J$. Biol. Chem. 257, 845-849.

Graham, R. M., Chua, A. C., Carter, K. W., Delima, R. D., Johnstone, D., Herbison, C. E., et al. (2010). Hepatic iron loading in mice increases cholesterol biosynthesis. Hepatology 52, 462-471. doi: 10.1002/hep. 23712

Grantham-McGregor, S., and Ani, C. (2001). A review of studies on the effect of iron deficiency on cognitive development in children. J. Nutr. 131, 649S-666S; discussion 666S-668S.

Guo, C., Wang, P., Zhong, M. L., Wang, T., Huang, X. S., Li, J. Y., et al. (2013a). Deferoxamine inhibits iron induced hippocampal tau phosphorylation in the Alzheimer transgenic mouse brain. Neurochem. Int. 62, 165-172. doi: 10.1016/j.neuint.2012.12.005

Guo, C., Wang, T., Zheng, W., Shan, Z. Y., Teng, W. P., and Wang, Z Y. (2013b). Intranasal deferoxamine reverses iron-induced memory deficits and inhibits amyloidogenic APP processing in a transgenic mouse model of Alzheimer's disease. Neurobiol. Aging 34, 562-575. doi: 10.1016/j.neurobiolaging.2012.05.009 Halliwell, B. (2006). Oxidative stress and neurodegeneration: where are we now? J. Neurochem. 97, 16341658. doi: 10.1111/j.1471-4159.2006. 03907.x
Hare, D. J., Adlard, P. A., Doble, P. A., and Finkelstein, D. I. (2013). Metallobiology of 1-methyl-4-phenyl1,2,3,6-tetrahydropyridine neurotoxicity. Metallomics 5, 91-109. doi: $10.1039 / \mathrm{c} 2 \mathrm{mt} 20164 \mathrm{j}$

He, Q., Du, T., Yu, X., Xie, A., Song, N., Kang, Q., et al. (2011). DMT1 polymorphism and risk of Parkinson's disease. Neurosci. Lett. 501, 128-131. doi: 10.1016/j.neulet.2011.07.001

Hening, W., Allen, R., Earley, C., Kushida, C., Picchietti, D., and Silber, M. (1999). The treatment of restless legs syndrome and periodic limb movement disorder. An American Academy of Sleep Medicine Review. Sleep 22, 970-999.

Hentze, M. W., Muckenthaler, M. U., and Andrews, N. C. (2004). Balancing acts: molecular control of mammalian iron metabolism. Cell 117, 285-297. doi: 10.1016/S00928674(04)00343-5

Hilditch-Maguire, P., Trettel, F., Passani, L. A., Auerbach, A., Persichetti, F., and Macdonald, M. E. (2000). Huntingtin: an iron-regulated protein essential for normal nuclear and perinuclear organelles. Hum. Mol. Genet. 9, 2789-2797. doi: 10.1093/hmg/9.19.2789

Hochstrasser, H., Bauer, P., Walter, U., Behnke, S., Spiegel, J., Csoti, I., et al. (2004). Ceruloplasmin gene variations and substantia nigra hyperechogenicity in Parkinson disease. Neurology 63, 1912-1917. doi: 10.1212/01.WNL.0000144276.29988.C3 Hollingworth, P., Harold, D., Sims, R., Gerrish, A., Lambert, J. C., Carrasquillo, M. M., et al. (2011). Common variants at ABCA7, MS4A6A/MS4A4E, EPHA1, CD33 and CD2AP are associated with Alzheimer's disease. Nat. Genet. 43, 429-435. doi: 10.1038/ng.803

Horowitz, M. P., and Greenamyre, J. T. (2010). Mitochondrial iron metabolism and its role in neurodegeneration. J. Alzheimers Dis. 20(Suppl. 2), S551-S568.

$\mathrm{Hu}$, J., and Connor, J. R. (1996). Demonstration and characterization of the iron regulatory protein in human brain. J. Neurochem. 67, 838-844. doi: 10.1046/j.14714159.1996.67020838.x

Huang, X., Atwood, C. S., Moir, R. D., Hartshorn, M. A., Tanzi, R. E., and Bush, A. I. (2004). Trace metal contamination initiates the apparent auto-aggregation, amyloidosis, and oligomerization of Alzheimer's Abeta peptides. J. Biol. Inorg. Chem. 9, 954960. doi: 10.1007/s00775-004-0602-8 Huang, X., Dai, J., Huang, C., Zhang, Q., Bhanot, O., and 
Pelle, E. (2007). Deferoxamine synergistically enhances iron-mediated AP-1 activation: a showcase of the interplay between extracellularsignal-regulated kinase and tyrosine phosphatase. Free Radic. Res. 41, 1135-1142. doi: 10.1080/ 10715760701609061

Huls, S., Hogen, T., Vassallo, N., Danzer, K. M., Hengerer, B., Giese, A., et al. (2011). AMPAreceptor-mediated excitatory synaptic transmission is enhanced by ironinduced alpha-synuclein oligomers. J. Neurochem. 117, 868-878. doi: 10.1111/j.1471-4159.2011.07254.x

Hunt, J. R., Zito, C. A., Erjavec, J., and Johnson, L. K. (1994). Severe or marginal iron deficiency affects spontaneous physical activity in rats. Am. J. Clin. Nutr. 59, 413-418.

Hurtado, E. K., Claussen, A. H., and Scott, K. G. (1999). Early childhood anemia and mild or moderate mental retardation. Am. J. Clin. Nutr. 69, 115-119.

Isaac, G., Fredriksson, A., Danielsson, R., Eriksson, P., and Bergquist, J. (2006). Brain lipid composition in postnatal iron-induced motor behavior alterations following chronic neuroleptic administration in mice. FEBS J. 273, 2232-2243. doi: 10.1111/j.1742-4658.2006.05236.x

Jarvis, J. H., and Jacobs, A. (1974). Morphological abnormalities in lymphocyte mitochondria associated with iron-deficiency anaemia. J. Clin. Pathol. 27, 973-979. doi: 10.1136/jcp.27.12.973

Jenkins, K. J., and Kramer, J. K. (1988). Effect of excess dietary iron on lipid composition of calf liver, heart, and skeletal muscle. J. Dairy Sci. 71, 435-441. doi: 10.3168/jds.S00220302(88)79573-9

Jeong, S. Y., Crooks, D. R., WilsonOllivierre, H., Ghosh, M. C., Sougrat, R., Lee, J., et al. (2011). Iron insufficiency compromises motor neurons and their mitochondrial function in Irp2-null mice. PLoS ONE 6:e25404. doi: 10.1371/journal.pone. 0025404

Juneja, M., Jain, R., Singh, V., and Mallika, V. (2010). Iron deficiency in Indian children with attention deficit hyperactivity disorder. Indian Pediatr. 47, 955-958. doi: 10.1007/s13312-010-0160-9

Jurgens, C. K., Jasinschi, R., Ekin, A., Witjes-Ane, M. N., Middelkoop, H., Van Der Grond, J., et al. (2010). MRI T2 Hypointensities in basal ganglia of premanifest Huntington's disease. PLoS Curr. 2:RRN1173. doi: $10.1371 /$ currents. RRN1173
Kaplan, P., Matejovicova, M., and Mezesova, V. (1997). Iron-induced inhibition of $\mathrm{Na}+, \mathrm{K}(+)$ ATPase and $\mathrm{Na}+/ \mathrm{Ca} 2+$ exchanger in synaptosomes: protection by the pyridoindole stobadine. Neurochem. Res. 22, 1523-1529. doi: 10.1023/A:1021918931780

Kastman, E. K., Willette, A. A., Coe, C. L., Bendlin, B. B., Kosmatka, K. J., Mclaren, D. G., et al. (2012). A calorie-restricted diet decreases brain iron accumulation and preserves motor performance in old rhesus monkeys. J. Neurosci. 32, 11897-11904. doi: 10.1523/ JNEUROSCI.2553-12.2012

Kaur, D., Peng, J., Chinta, S. J., Rajagopalan, S., Di Monte, D. A., Cherny, R. A., et al. (2007). Increased murine neonatal iron intake results in Parkinson-like neurodegeneration with age. Neurobiol. Aging 28, 907-913. doi: 10.1016/ j.neurobiolaging.2006.04.003

Kaur, D., Yantiri, F., Rajagopalan, S. Kumar, J., Mo, J. Q., Boonplueang, R., etal. (2003). Genetic or pharmacological iron chelation prevents MPTP-induced neurotoxicity in vivo: a novel therapy for Parkinson's disease. Neuron 37, 899-909. doi: 10.1016/S0896-6273(03)00126-0

Kauwe, J. S., Bertelsen, S., Mayo, K. Cruchaga, C., Abraham, R., Hollingworth, P., et al. (2010). Suggestive synergy between genetic variants in TF and HFE as risk factors for Alzheimer's disease. Am. J. Med. Genet. B Neuropsychiatr. Genet. 153B, 955-959. doi: 10.1002/ajmg.b.31053

Kawabata, H., Yang, R., Hirama, T., Vuong, P. T., Kawano, S., Gombart, A. F., et al. (1999). Molecular cloning of transferrin receptor 2. A new member of the transferrin receptor-like family. J. Biol. Chem. 274, 20826-20832. doi: 10.1074/jbc.274.30.20826

Ke, Y., and Ming Qian, Z. (2003). Iron misregulation in the brain: a primary cause of neurodegenerative disorders. Lancet Neurol. 2, 246253. doi: 10.1016/S1474-4422(03) 00353-3

Khan, A., Dobson, J. P., and Exley, C. (2006). Redox cycling of iron by Abeta42. Free Radic. Biol. Med. 40, 557-569. doi: 10.1016/j. freeradbiomed.2005.09.013

Khatoon, S., Grundke-Iqbal, I., and Iqbal, K. (1994). Levels of normal and abnormally phosphorylated tau in different cellular and regional compartments of Alzheimer disease and control brains. FEBS Lett. 351, 80-84. doi: 10.1016/0014-5793(94)00829-9

Kidani, Y., Naga, S., and Koike, H. (1974). Mass spectrophotometry of 5-chloro-7iodo-8-quinolinol metal chelates. Jpn. Anal. 23, 1375 1378. doi: 10.2116/bunsekikagaku. 23.1375

Knutson, M. D., Walter, P. B., Ames, B. N., and Viteri, F. E. (2000). Both iron deficiency and daily iron supplements increase lipid peroxidation in rats. $J$. Nutr. 130, 621-628.

Konofal, E., Cortese, S., Lecendreux, M., Arnulf, I., and Mouren, M. C. (2005). Effectiveness of iron supplementation in a young child with attention-deficit/hyperactivity disorder. Pediatrics 116, e732-e734. doi: 10.1542/peds.2005-0715

Konofal, E., Lecendreux, M., Arnulf, I., and Mouren, M. C. (2004). Iron deficiency in children with attention-deficit/hyperactivity disorder. Arch. Pediatr. Adolesc. Med. 158, 1113-1115. doi: 10.1001/archpedi.158.12.1113

Konofal, E., Lecendreux, M., Deron, J., Marchand, M., Cortese, S., Zaim, M., etal. (2008). Effects of iron supplementation on attention deficit hyperactivity disorder in children. Pediatr. Neurol. 38, 20-26. doi: 10.1016/j.pediatrneurol.2007.08.014 Kontoghiorghes, G. J., Aldouri, M. A., Hoffbrand, A. V., Barr, J., Wonke, B., Kourouclaris, T., et al. (1987a). Effective chelation of iron in beta thalassaemia with the oral chelator 1,2-dimethyl-3hydroxypyrid-4-one. $\mathrm{Br}$. Med. J. (Clin. Res. Ed.) 295, 1509-1512. doi: 10.1136/bmj.295.6612.1509

Kontoghiorghes, G. J., Aldouri, M. A., Sheppard, L., and Hoffbrand, A. V. (1987b). 1,2-Dimethyl-3hydroxypyrid-4-one, an orally active chelator for treatment of iron overload. Lancet 1, 1294-1295. doi: 10.1016/S0140-6736(87)90545-9

Kosta, P., Argyropoulou, M. I., Markoula, S., and Konitsiotis, S. (2006). MRI evaluation of the basal ganglia size and iron content in patient with Parkinson's disease. J. Neurol. 253, 26-32. doi: 10.1007/s00415-005 0914-9

Kostka, M., Hogen, T., Danzer, K. M., Levin, J., Habeck, M., Wirth, A. etal. (2008). Single particle characterization of iron-induced poreforming alpha-synuclein oligomers. J. Biol. Chem. 283, 10992-11003. doi 10.1074/jbc.M709634200

Kraml, P. J., Klein, R. L., Huang, Y., Nareika, A., and Lopes-Virella, M. F. (2005). Iron loading increases cholesterol accumulation and macrophage scavenger receptor I expression in THP-1 mononuclear phagocytes. Metabolism 54, 453-459. doi: 10.1016/j.metabol.2004.10.012
Ksiezak-Reding, H., Binder, L. I., and Yen, S.-H. C. (1988). Immunochemical and biochemical characterization of tau proteins in normal and Alzheimer's disease brains with $\mathrm{Alz}$ 50 and Tau-1. J. Biol. Chem. 263, 7948-7953.

Kuhn, D. M., Ruskin, B., and Lovenberg, W. (1980). Tryptophan hydroxylase. The role of oxygen, iron, and sulfhydryl groups as determinants of stability and catalytic activity. J. Biol. Chem. 255, 4137-4143.

Kuperstein, F., and Yavin, E. (2003). Pro-apoptotic signaling in neuronal cells following iron and amyloid beta peptide neurotoxicity. J. Neurochem. 86, 114-125. doi: 10.1046/j.14714159.2003.01831.x

Langkammer, C., Enzinger, C., Quasthoff, S., Grafenauer, P., Soellinger, M., Fazekas, F., et al. (2010). Mapping of iron deposition in conjunction with assessment of nerve fiber tract integrity in amyotrophic lateral sclerosis. J. Magn. Reson. Imaging 31, 1339-1345. doi: 10.1002/jmri.22185

Lavigne, G. J., and Montplaisir, J. Y. (1994). Restless legs syndrome and sleep bruxism: prevalence and association among Canadians. Sleep 17, 739-743.

Lehmann, D. J., Schuur, M., Warden, D. R., Hammond, N., Belbin, O., Kolsch, H., et al. (2012). Transferrin and HFE genes interact in Alzheimer's disease risk: the Epistasis Project. Neurobiol. Aging 33, 202 e201-e213.

Lei, P., Ayton, S., Bush, A. I., and Adlard, P. A. (2011). GSK-3 in Neurodegenerative Diseases. Int. J. Alzheimers Dis. 2011, 189246. doi: 10.4061/2011/189246

Lei, P., Ayton, S., Finkelstein, D. I., Adlard, P. A., Masters, C. L., and Bush, A. I. (2010). Tau protein: relevance to Parkinson's disease. Int. J. Biochem. Cell Biol. 42, 17751778. doi: 10.1016/j.biocel.2010.07. 016

Lei, P., Ayton, S., Finkelstein, D. I., Spoerri, L., Ciccotosto, G. D., Wright, D. K., et al. (2012). Tau deficiency induces parkinsonism with dementia by impairing APP-mediated iron export. Nat. Med. 18, 291-295. doi: $10.1038 / \mathrm{nm} .2613$

Leitner, D. F., and Connor, J. R. (2012). Functional roles of transferrin in the brain. Biochim. Biophys. Acta 1820, 393-402. doi: 10.1016/j.bbagen.2011.10.016

Leskovjan, A. C., Kretlow, A., Lanzirotti, A., Barrea, R., Vogt, S., and Miller, L. M. (2011). Increased brain iron coincides with early plaque formation in a mouse model of Alzheimer's 
disease. Neuroimage 55, 32-38. doi: 10.1016/j.neuroimage.2010.11.073

Lhermitte, J., Kraus, W. M., and Mcalpine, D. (1924). Original Papers: on the occurrence of abnormal deposits of iron in the brain in parkinsonism with special reference to its localisation. J. Neurol. Psychopathol. 5, 195-208. doi: 10.1136/jnnp.s1-5.19.195

Li, C., Wang, J., and Zhou, B. (2010). The metal chelating and chaperoning effects of clioquinol: insights from yeast studies. J. Alzheimers Dis. 21, 1249-1262.

Li, W., Jiang, H., Song, N., and Xie, J. (2011). Oxidative stress partially contributes to iron-induced alphasynuclein aggregation in SK-N-SH cells. Neurotox. Res. 19, 435-442. doi: 10.1007/s12640-010-9187-x

Liang, L.-P., Jarrett, S. G., and Patel, M. (2008). Chelation of mitochondrial iron prevents seizure-induced mitochondrial dysfunction and neuronal injury. $J$. Neurosci. 28, 11550-11556. doi: 10.1523/JNEUROSCI.3016-08.2008

Lis, A., Paradkar, P. N., Singleton, S., Kuo, H.-C., Garrick, M. D., and Roth, J.A. (2005). Hypoxia induces changes in expression of isoforms of the divalent metal transporter (DMT1) in rat pheochromocytoma (PC12) cells. Biochem. Pharmacol. 69, 16471655. doi: 10.1016/j.bcp.2005.03. 023

Litwin, T., Gromadzka, G., Szpak, G. M., Jablonka-Salach, K., Bulska, E., and Czlonkowska, A. (2013). Brain metal accumulation in Wilson's disease. J. Neurol. Sci. 329, 55-58. doi: 10.1016/j.jns.2013.03.021

Liu, B., Moloney, A., Meehan, S., Morris, K., Thomas, S. E., Serpell, L. C., et al. (2011). Iron promotes the toxicity of amyloid beta peptide by impeding its ordered aggregation. J. Biol. Chem. 286, 4248-4256. doi: 10.1074/jbc.M110.158980

Loef, M., and Walach, H. (2012). Copper and iron in Alzheimer's disease: a systematic review and its dietary implications. Br. J. Nutr. 107, 7-19. doi: 10.1017/S000711451100376X

Loeffler, D. A., Connor, J. R., Juneau, P. L., Snyder, B. S., Kanaley, L., Demaggio, A. J., et al. (1995). Transferrin and iron in normal, Alzheimer's disease, and Parkinson's disease brain regions. J. Neurochem. 65, 710-724. doi: 10.1046/j.14714159.1995.65020710.x

Lok, C. N., and Ponka, P. (1999). Identification of a hypoxia response element in the transferrin receptor gene. J. Biol. Chem. 274, 24147-24152. doi: 10.1074/jbc. 274.34 .24147
Looker, A. C., Dallman, P. R., Carroll, M. D., Gunter, E. W., and Johnson, C. L. (1997). Prevalence of iron deficiency in the United States. JAMA 277, 973-976. doi: 10.1001/jama.1997.03540360041028 Lovell, M. A., Robertson, J. D., Teesdale, W. J., Campbell, J. L., and Markesbery, W. R. (1998). Copper, iron and zinc in Alzheimer's disease senile plaques. J. Neurol. Sci. 158, 47-52. doi: 10.1016/S0022-510X(98) 00092-6

Lovell, M. A., Xiong, S., Xie, C., Davies, P. L., and Markesbery, W. R. (2004). Induction of hyperphosphorylated tau in primary rat cortical neuron cultures mediated by oxidative stress and glycogen synthase kinase-3. J. Alzheimers Dis. 6, 659-671; discussion 673-681.

Lozoff, B., Jimenez, E., Hagen, J., Mollen, E., and Wolf, A. W. (2000). Poorer behavioral and developmental outcome more than 10 years after treatment for iron deficiency in infancy. Pediatrics 105, E51. doi: 10.1542/peds.105.4.e51

Lozoff, B., Jimenez, E., and Wolf, A. W. (1991). Long-term developmental outcome of infants with iron deficiency. N. Engl. J. Med. 325, 687-694. doi: 10.1056/ NEJM199109053251004

Lumsden, A. L., Henshall, T. L., Dayan, S., Lardelli, M. T., and Richards, R. I. (2007). Huntingtin-deficient zebrafish exhibit defects in iron utilization and development. Hum. Mol. Genet. 16, 1905-1920. doi: $10.1093 / \mathrm{hmg} / \mathrm{ddm} 138$

Machado, A., Chien, H. F., Deguti, M. M., Cancado, E., Azevedo, R. S., Scaff, M., et al. (2006). Neurological manifestations in Wilson's disease: report of 119 cases. Mov. Disord. 21, 2192-2196. doi: 10.1002/mds. 21170

Mandel, S., Maor, G., and Youdim, M. B. (2004). Iron and alpha-synuclein in the substantia nigra of MPTPtreated mice: effect of neuroprotective drugs R-apomorphine and green tea polyphenol (-)-epigallocatechin3-gallate. J. Mol. Neurosci. 24, 401416. doi: 10.1385/JMN:24:3:401

Mantyh, P. W., Ghilardi, J. R., Rogers, S., Demaster, E., Allen, C. J., Stimson, E. R., et al. (1993). Aluminum, iron, and zinc ions promote aggregation of physiological concentrations of beta-amyloid peptide. J. Neurochem. 61, 1171-1174. doi: 10.1111/j.14714159.1993.tb03639.x

Martin, W. R., Wieler, M., and Gee, M. (2008). Midbrain iron content in early Parkinson disease: a potential biomarker of disease status. Neurology 70, 1411-1417. doi: $\quad$ 10.1212/01.wnl.0000286384 31050.b5

Martin, W. R., Ye, F. Q., and Allen, P. S. (1998). Increasing striatal iron content associated with normal aging. Mov. Disord. 13, 281-286. doi: $10.1002 / \mathrm{mds} .870130214$

Mash, D. C., Pablo, J., Buck, B. E., Sanchez-Ramos, J., and Weiner, W. J. (1991). Distribution and number of transferrin receptors in Parkinson's disease and in MPTP-treated mice. Exp. Neurol. 114, 73-81. doi: 10.1016/0014-4886(91)90086-R

Masini, A., Trenti, T., Caramazza, I., Predieri, G., Gallesi, D., and Ceccarelli, D. (1994). Dietary iron deficiency in the rat. II. Recovery from energy metabolism derangement of the hepatic tissue by iron therapy. Biochim. Biophys. Acta 1188 , 53-57. doi: 10.1016/0005-2728(94) 90021-3

Mastroberardino, P. G., Hoffman, E. K., Horowitz, M. P., Betarbet, R. Taylor, G., Cheng, D., et al. (2009). A novel transferrin/TfR2-mediated mitochondrial iron transport system is disrupted in Parkinson's disease. Neurobiol. Dis. 34, 417-431. doi: 10.1016/j.nbd.2009.02.009

Mattson, M. P. (2004). Metal-catalyzed disruption of membrane protein and lipid signaling in the pathogenesis of neurodegenerative disorders. Ann. N. Y. Acad. Sci. 1012, 37-50. doi: 10.1196/annals.1306.004

McNeill, A., Pandolfo, M., Kuhn, J., Shang, H., and Miyajima, H. (2008). The neurological presentation of ceruloplasmin gene mutations. Eur. Neurol. 60, 200-205. doi: 10.1159/000148691

Meadowcroft, M. D., Connor, J. R., Smith, M. B., and Yang, Q. X. (2009). MRI and histological analysis of beta-amyloid plaques in both human Alzheimer's disease and APP/PS1 transgenic mice. J. Magn. Reson. Imaging 29, 997-1007. doi: 10.1002/jmri.21731

Meloni, A., Positano, V., Pepe, A., Rossi, G., Dell'amico, M., Salvatori, C., et al. (2010). Preferential patterns of myocardial iron overload by multislice multiecho $\mathrm{T}^{\star} 2$ CMR in thalassemia major patients. Magn. Reson. Med. 64, 211-219. doi: 10.1002/mrm.22410

Menegassi, M., Mello, E. D., Guimaraes, L. R., Matte, B. C., Driemeier F., Pedroso, G. L., et al. (2010). Food intake and serum levels of iron in children and adolescents with attention-deficit/hyperactivity disorder. Rev. Bras. Psiquiatr. 32, 132 138. doi: 10.1590/S1516-4446200900 5000008
Michaud, M., Soucy, J. P., Chabli, A., Lavigne, G., and Montplaisir, J. (2002). SPECT imaging of striatal pre- and postsynaptic dopaminergic status in restless legs syndrome with periodic leg movements in sleep. J. Neurol. 249, 164-170. doi: 10.1007/PL00007859

Mitchell, R. M., Lee, S. Y., Simmons, Z., and Connor, J. R. (2011). HFE polymorphisms affect cellular glutamate regulation. $\mathrm{Neu}$ robiol. Aging 32, 1114-1123. doi: 10.1016/j.neurobiolaging.2009.05. 016

Miyajima, H., Nishimura, Y., Mizoguchi, K., Sakamoto, M., Shimizu, T., and Honda, N. (1987). Familial apoceruloplasmin deficiency associated with blepharospasm and retinal degeneration. Neurology 37, 761-767. doi: 10.1212/WNL.37.5. 761

Moos, T., and Morgan, E. H. (2004). The significance of the mutated divalent metal transporter (DMT1) on iron transport into the Belgrade rat brain. J. Neurochem. 88, 233-245. doi: 10.1046/j.1471-4159.2003.02142.x

Moos, T., Nielsen, T. R., Skjørringe, T., and Morgan, E. H. (2007). Iron trafficking inside the brain. J. Neurochem. 103, 1730-1740.

Moos, T., and Rosengren Nielsen, T. (2006). Ferroportin in the postnatal rat brain: implications for axonal transport and neuronal export of iron. Semin. Pediatr. Neurol. 13, 149157. doi: 10.1016/j.spen.2006.08. 003

Moos, T., Skjoerringe, T., Gosk, S., and Morgan, E. H. (2006). Brain capillary endothelial cells mediate iron transport into the brain by segregating iron from transferrin without the involvement of divalent metal transporter 1. J. Neurochem. 98, 1946-1958. doi: 10.1111/j.1471-4159.2006.04023.x

Morath, D. J., Mayer, P., Ouml, and Schel, M. (2002). Iron deficiency during embryogenesis and consequences for oligodendrocyte generation in vivo. Dev. Neurosci. 24, 197-207.

Morath, D. J., and Mayer-Proschel, M. (2001). Iron modulates the differentiation of a distinct population of glial precursor cells into oligodendrocytes. Dev. Biol. 237, 232-243. doi: 10.1006/dbio.2001.0352

Moreau, V. H., Castilho, R. F., Ferreira, S. T., and Carvalho-Alves, P. C. (1998). Oxidative damage to sarcoplasmic reticulum $\mathrm{Ca} 2+$-ATPase AT submicromolar iron concentrations: evidence for metal-catalyzed oxidation. Free Radic. Biol. Med. 25, 554-560. doi: 10.1016/S08915849(98)00084-7 
Morgan, E. H., and Moos, T. (2002). Mechanism and developmental changes in iron transport across the blood-brain brrier. Dev. Neurosci. 24, 106-113. doi: 10.1159/000065699

Morris, C. M., Candy, J. M., Omar, S., Bloxham, C. A., and Edwardson, J. A. (1994). Transferrin receptors in the parkinsonian midbrain. Neuropathol. Appl. Neurobiol. 20, 468-472. doi: 10.1111/j.1365-2990.1994.tb00997.x

Munoz, P., Humeres, A., Elgueta, C., Kirkwood, A., Hidalgo, C., and Nunez, M. T. (2011). Iron mediates N-methyl-D-aspartate receptordependent stimulation of calciuminduced pathways and hippocampal synaptic plasticity. J. Biol. Chem. 286, 13382-13392. doi: 10.1074/jbc.M110.213785

Muñoz, P., Zavala, G., Castillo, K., Aguirre, P., Hidalgo, C., and Nuñez, M. T. (2006). Effect of iron on the activation of the MAPK/ERK pathway in PC12 neuroblastoma cells. Biol. Res. 39, 189-190.

Murphy, C. J., and Oudit, G. Y. (2010). Iron-overload cardiomyopathy: pathophysiology, diagnosis, and treatment. J. Card. Fail. 16, 888-900. doi: 10.1016/j.cardfail.2010.05.009

Nakamichi, N., Ohno, H., Nakamura, Y., Hirai, T., Kuramoto, N., and Yoneda, Y. (2002). Blockade by ferrous iron of $\mathrm{Ca} 2+$ influx through $\mathrm{N}$ methyl-D-aspartate receptor channels in immature cultured rat cortical neurons. J. Neurochem. 83, 1-11. doi: 10.1046/j.1471-4159.2002.01042.x

Nakamura, M., Shishido, N., Nunomura, A., Smith, M. A., Perry, G., Hayashi, Y., et al. (2007). Three histidine residues of amyloid-beta peptide control the redox activity of copper and iron. Biochemistry 46, $12737-$ 12743. doi: 10.1021/bi701079z

Nick, H. (2007). Iron chelation, quo vadis? Curr. Opin. Chem. Biol. 11, 419-423. doi: 10.1016/ j.cbpa.2007.04.025

Nitzan, Y. B., Sekler, I., Frederickson, C. J., Coulter, D. A., Balaji, R. V., Liang, S. L., et al. (2003). Clioquinol effects on tissue chelatable zinc in mice. $J$. Mol. Med. (Berl.) 81, 637-644. doi: 10.1007/s00109-003-0462-7

Oba, H., Araki, T., Ohtomo, K., Monzawa, S., Uchiyama, G., Koizumi, K., et al. (1993). Amyotrophic lateral sclerosis: T2 shortening in motor cortex at MR imaging. Radiology 189, 843-846.

Ohtsuka, K., Ohishi, N., Eguchi, G., and Yagi, K. (1982). Degeneration of retinal neuroblasts by chinoform-ferric chelate. Experientia 38, 120-122. doi: 10.1007/BF01944564
Oner, O., Alkar, O. Y., and Oner, P. (2008). Relation of ferritin levels with symptom ratings and cognitive performance in children with attention deficit-hyperactivity disorder. Pediatr. Int. 50, 40-44. doi 10.1111/j.1442-200X.2007.02496.x

Ortiz, E., Pasquini, J. M., Thompson, K., Felt, B., Butkus, G., Beard, J., et al. (2004). Effect of manipulation of iron storage, transport, or availability on myelin composition and brain iron content in three different animal models. J. Neurosci. Res. 77, 681-689. doi: 10.1002/jnr.20207

Osaki, S., Johnson, D. A., and Frieden, E. (1966). The possible significance of the ferrous oxidase activity of ceruloplasmin in normal human serum. $J$. Biol. Chem. 241, 2746-2751.

Ostrerova-Golts, N., Petrucelli, L., Hardy, J., Lee, J. M., Farer, M., and Wolozin, B. (2000). The A53T alphasynuclein mutation increases irondependent aggregation and toxicity. J. Neurosci. 20, 6048-6054.

Palti, H., Meijer, A., and Adler, B. (1985). Learning achievement and behavior at school of anemic and non-anemic infants. Early Hum. Dev. 10, 217-223. doi: 10.1016/0378-3782(85)90052-0

Pantopoulos, K. (2004). Iron metabolism and the IRE/IRP regulatory system: an update. Ann. N. Y. Acad. Sci. 1012, 1-13. doi: 10.1196/annals. 1306.001

Park, M. H., Lee, S. J., Byun, H. R., Kim, Y., Oh, Y. J., Koh, J. Y., et al. (2011). Clioquinol induces autophagy in cultured astrocytes and neurons by acting as a zinc ionophore. Neurobiol. Dis. 42, 242-251. doi: 10.1016/j.nbd.2011. 01.009

Patel, B. N., Dunn, R. J., Jeong, S. Y., Zhu, Q., Julien, J.-P., and David, S. (2002). Ceruloplasmin regulates iron levels in the CNS and prevents free radical injury. J. Neurosci. 22, 6578-6586.

Peng, Y., Wang, C., Xu, H. H., Liu, Y. N., and Zhou, F. (2010). Binding of alpha-synuclein with $\mathrm{Fe}$ (III) and with $\mathrm{Fe}$ (II) and biological implications of the resultant complexes. J. Inorg. Biochem. 104, 365-370. doi: 10.1016/j.jinorgbio.2009.11.005

Penke, L., Valdes Hernandez, M. C., Maniega, S. M., Gow, A. J., Murray, C., Starr, J. M., et al. (2012). Brain iron deposits are associated with general cognitive ability and cognitive aging. Neurobiol. Aging 33, 510517.e2.

Peyssonnaux, C., Nizet, V., and Johnson, R. S. (2008). Role of the hypoxia inducible factors HIF in iron metabolism. Cell cycle 7, 28-32. doi: 10.4161/cc.7.1.5145
Pfefferbaum, A., Adalsteinsson, E., Rohlfing, T., and Sullivan, E. V. (2009). MRI estimates of brain iron concentration in normal aging: comparison of field-dependent (FDRI) and phase (SWI) methods. Neuroimage 47, 493-500. doi: $\quad$ 10.1016/j.neuroimage. 2009 . 05.006

Pietrangelo, A. (2010). Hereditary hemochromatosis: pathogenesis, diagnosis, and treatment. Gastroenterology 139, 393-408, e2.

Piga, A., Galanello, R., Forni, G. L., Cappellini, M. D., Origa, R., Zappu, A., et al. (2006). Randomized phase II trial of deferasirox (Exjade, ICL670), a once-daily, orally-administered iron chelator, in comparison to deferoxamine in thalassemia patients with transfusional iron overload. Haematologica 91, 873-880.

Popescu, B. F., George, M. J., Bergmann, U., Garachtchenko, A. V., Kelly, M. E., Mccrea, R. P., et al. (2009). Mapping metals in Parkinson's and normal brain using rapid-scanning $\mathrm{x}$ ray fluorescence. Phys. Med. Biol. 54, 651-663. doi: 10.1088/00319155/54/3/012

Positano, V., Salani, B., Pepe, A., Santarelli, M. F., De Marchi, D., Ramazzotti, A., et al. (2009). Improved $\mathrm{T} 2 *$ assessment in liver iron overload by magnetic resonance imaging. Magn. Reson. Imaging 27, 188-197. doi: 10.1016/ j.mri.2008.06.004

Propper, R. D., Shurin, S. B., and Nathan, D. G. (1976). Reassessment of the use of desferrioxamine B in iron overload. N. Engl. J. Med. 294, 1421-1423. doi: 10.1056/NEJM197606242942603

Puccio, H., Simon, D., Cossee, M., Criqui-Filipe, P., Tiziano, F., Melki, J., etal. (2001). Mouse models for Friedreich ataxia exhibit cardiomyopathy, sensory nerve defect and $\mathrm{Fe}-\mathrm{S}$ enzyme deficiency followed by intramitochondrial iron deposits. Nat. Genet. 27, 181-186. doi: $10.1038 / 84818$

Qin, Y., Zhu, W., Zhan, C., Zhao, L., Wang, J., Tian, Q., et al. (2011). Investigation on positive correlation of increased brain iron deposition with cognitive impairment in Alzheimer disease by using quantitative MR R2' mapping. J. Huazhong Univ. Sci. Technolog. Med. Sci. 31, 578-585. doi: 10.1007/s11596-011-0493-1

Ramsey, A. J., Hillas, P. J., and Fitzpatrick, P. F. (1996). Characterization of the active site iron in tyrosine hydroxylase. Redox states of the iron. J. Biol. Chem. 271, 24395-24400. doi: 10.1074/jbc. 271.40 .24395
Ratcliffe, P. J., Maxwell, P. H., Wiesener, M. S., Chang, G.-W., Clifford, S. C., Vaux, E. C., et al. (1999). The tumour suppressor protein VHL targets hypoxia-inducible factors for oxygen-dependent proteolysis. Nat. Genet. 399, 271-275. doi: 10.1038/20459

Redfearn, E. R., and King, T. E. (1964). Mitochondrial Nadh2 Dehydrogenase and Nadh2 Oxidase from Heart Muscle: possible existence of a ferredoxin-like component in the respiratory chain. Nature 202, 13131316. doi: 10.1038/2021313a0

Reznichenko, L., Kalfon, L., Amit, T., Youdim, M. B., and Mandel, S. A. (2010). Low dosage of rasagiline and epigallocatechin gallate synergistically restored the nigrostriatal axis in MPTP-induced parkinsonism. Neurodegener. Dis. 7, 219-231. doi: 10.1159/000265946

Richardson, D. R., Lane, D. J., Becker, E. M., Huang, M. L., Whitnall, M., Suryo Rahmanto, Y., et al. (2010). Mitochondrial iron trafficking and the integration of iron metabolism between the mitochondrion and cytosol. Proc. Natl. Acad. Sci. U.S.A. 107, 10775-10782. doi: 10.1073/pnas.0912925107

Ritchie, C. W., Bush, A. I., Mackinnon, A., Macfarlane, S., Mastwyk, M., Macgregor, L., et al. (2003). Metal-protein attenuation with iodochlorhydroxyquin (clioquinol) targeting Abeta amyloid deposition and toxicity in Alzheimer disease: a pilot phase 2 clinical trial. Arch. Neurol. 60, 16851691. doi: 10.1001/archneur.60.12. 1685

Rival, T., Page, R. M., Chandraratna, D. S., Sendall, T. J., Ryder, E., Liu, B., et al. (2009). Fenton chemistry and oxidative stress mediate the toxicity of the beta-amyloid peptide in a Drosophila model of Alzheimer's disease. Eur. J. Neurosci. 29, 1335-1347. doi: 10.1111/j.14609568.2009.06701.x

Rogers, J. T., Bush, A. I., Cho, H. H., Smith, D. H., Thomson, A. M., Friedlich, A. L., et al. (2008). Iron and the translation of the amyloid precursor protein (APP) and ferritin mRNAs: riboregulation against neural oxidative damage in Alzheimer's disease. Biochem. Soc. Trans. 36, 1282-1287. doi: 10.1042/BST0361282

Rogers, J. T., Randall, J. D., Cahill, C. M., Eder, P. S., Huang, X., Gunshin, H., et al. (2002). An iron-responsive element type II in the $5^{\prime}$-untranslated region of the Alzheimer's amyloid precursor protein transcript. J. Biol. 
Chem. 277, 45518-45528. doi: 10.1074/jbc.M207435200

Rolfs, A., Kvietikova, I., Gassmann, M., and Wenger, R. H. (1997). Oxygen-regulated transferrin expression is mediated by hypoxia-inducible factor-1. J. Biol. Chem. 272, 20055-20062. doi: 10.1074/jbc.272.32.20055

Roncagliolo, M., Garrido, M., Walter, T., Peirano, P., and Lozoff, B. (1998). Evidence of altered central nervous system development in infants with iron deficiency anemia at 6 mo: delayed maturation of auditory brainstem responses. Am. J. Clin. Nutr. 68, 683-690.

Rosas, H. D., Chen, Y. I., Doros, G., Salat, D. H., Chen, N. K., Kwong, K. K., etal. (2012). Alterations in brain transition metals in Huntington disease: an evolving and intricate story. Arch. Neurol. 69, 887-93. doi: 10.1001/archneurol.2011.2945

Roskams, A. J., and Connor, J. R. (1994). Iron, transferrin, and ferritin in the rat brain during development and aging. J. Neurochem. 63, 709-716. doi: 10.1046/j.14714159.1994.63020709.x

Rothdach, A. J., Trenkwalder, C., Haberstock, J., Keil, U., and Berger, K. (2000). Prevalence and risk factors of RLS in an elderly population: the MEMO study. Neurology 54, 1064 1068. doi: 10.1212/WNL.54.5.1064

Rottkamp, C. A., Raina, A. K., Zhu, X. W., Gaier, E., Bush, A. I., Atwood, C. S., et al. (2001). Redox-active iron mediates amyloid-beta toxicity. Free Radic. Biol. Med. 30, 447-450. doi: 10.1016/S0891-5849(00)00494-9

Russell, M. J., Daniel, R. M., and Hall, A. J. (1993). On the emergence of life via catalytic iron-sulphide membranes. Terra Nova 5, 343-347. doi: 10.1111/j.1365-3121.1993.tb00267.x

Salazar, J., Mena, N., Hunot, S., Prigent, A., Alvarez-Fischer, D., Arredondo, M., etal. (2008). Divalent metal transporter 1 (DMT1) contributes to neurodegeneration in animal models of Parkinson's disease. Proc. Natl. Acad. Sci. U.S.A. 105, 18578-18583. doi: 10.1073/pnas.0804373105

Sampietro, M., Caputo, L., Casatta, A., Meregalli, M., Pellagatti, A., Tagliabue, J., et al. (2001). The hemochromatosis gene affects the age of onset of sporadic Alzheimer's disease. Neurobiol. Aging 22, 563-568. doi: 10.1016/S0197-4580(01)00219-6

SanMartin, C. D., Paula-Lima, A C., Hidalgo, C., and Nunez, M. T. (2012). Sub-lethal levels of amyloid beta-peptide oligomers decrease non-transferrin-bound iron uptake and do not potentiate iron toxicity in primary hippocampal neurons. Biometals 25, 805-813. doi: 10.1007/s10534-012-9545-7

Santillo, A. F., Skoglund, L., Lindau, M., Eeg-Olofsson, K. E., Tovi, M., Engler, H., et al. (2009). Frontotemporal dementia-amyotrophic lateral sclerosis complex is simulated by neurodegeneration with brain iron accumulation. Alzheimer Dis. Assoc. Disord. 23, 298-300. doi: 10.1097/WAD.0b013e3181a2b76b

Sayre, L. M., Perry, G., Harris, P. L., Liu, Y., Schubert, K. A., and Smith, M A. (2000). In situ oxidative catalysis by neurofibrillary tangles and senile plaques in Alzheimer's disease: a central role for bound transition metals. J. Neurochem. 74, 270-279. doi: 10.1046/j.1471-4159.2000.0740270.x

Schjeide, B. M., Mcqueen, M. B. Mullin, K., Divito, J., Hogan, M. F., Parkinson, M., et al. (2009). Assessment of Alzheimer's disease casecontrol associations using familybased methods. Neurogenetics 10 19-25. doi: 10.1007/s10048-0080151-3

Schneider, S. A., Hardy, J., and Bhatia, K. P. (2012). Syndromes of neurodegeneration with brain iron accumulation (NBIA): an update on clinical presentations, histological and genetic underpinnings, and treatment considerations. Mov. Disord. 27, 42-53. doi: $10.1002 / \mathrm{mds} .23971$

Schubert, D., and Chevion, M. (1995). The role of iron in beta amyloid toxicity. Biochem. Biophys. Res. Commun. 216, 702-707. doi: 10.1006/bbrc. 1995.2678

Semenza, G. L. (2000). HIF-1 and human disease: one highly involved factor. Genes Dev. 14, 1983-1991.

Shashaty, G., Frankewich, R. Chakraborti, T., Choudary, J. Al-Fayoumi, S., Kacuba, A., et al. (2006). Deferasirox for the treatment of chronic iron overload in transfusional hemosiderosis. Oncology (Williston Park) 20, 1799-1806, 1811; discussion 1811-1713, 1817.

Shin, R. W., Iwaki, T., Kitamoto, T., Sato, Y., and Tateishi, J. (1992). Massive accumulation of modified tau and severe depletion of normal tau characterize the cerebral cortex and white matter of Alzheimer's disease. Demonstration using the hydrated autoclaving method. Am. J. Pathol. 140, 937-945.

Shin, R.-W., Kruck, T. P. A., Murayama, H., and Kitamoto, T. (2003). A novel trivalent cation chelator Feralex dissociates binding of aluminum and iron associated with hyperphosphorylated tau of Alzheimer's disease. Brain Res.
961, 139-146. doi: 10.1016/S0006 8993(02)03893-3

Shinkyo, R., and Guengerich, F. P. (2011). Cytochrome P450 7A1 cholesterol 7alpha-hydroxylation: individual reaction steps in the catalytic cycle and rate-limiting ferric iron reduction. J. Biol. Chem. 286, 4632-4643. doi: 10.1074/jbc.M110.193409

Shiono, Y., Wakusawa, S., Hayashi, H., Takikawa, T., Yano, M., Okada, T., et al. (2001). Iron accumulation in the liver of male patients with Wilson's disease. Am. J. Gastroenterol. 96, 3147-3151. doi: 10.1111/j.15720241.2001.05269.x

Siddappa, A. J. M., Rao, R. B., Wobken, J. D., Casperson, K., Leibold, E. A., Connor, J. R., et al. (2003). Iron deficiency alters iron regulatory protein and iron transport protein expression in the perinatal rat brain. Pediatr. Res. 53, 800-807. doi: 10.1203/01.PDR.0000058922.67035.D

Simmons, D. A., Casale, M., Alcon, B. Pham, N., Narayan, N., and Lynch, G. (2007). Ferritin accumulation in dystrophic microglia is an early event in the development of Huntington's disease. Glia 55, 1074-1084. doi: 10.1002/glia.20526

Singh, A., Haldar, S., Horback, K., Tom, C., Zhou, L., Meyerson, H., et al. (2013). Prion protein regulates iron transport by functioning as a ferrireductase. J. Alzheimers Dis. 35, 541-552.

Singh, A., Isaac, A. O., Luo, X., Mohan, M. L., Cohen, M. L., Chen, F., et al. (2009a). Abnormal brain iron homeostasis in human and animal prion disorders. PLoS Pathog. 5:e1000336. doi: 10.1371/journal. ppat. 1000336

Singh, A., Kong, Q., Luo, X., Petersen, R. B., Meyerson, H., and Singh, N. (2009b). Prion protein (PrP) knock-out mice show altered iron metabolism: a functional role for PrP in iron uptake and transport. PLoS ONE 4:e6115. doi: 10.1371/journal.pone.0006115

Singh, A., Mohan, M. L., Isaac, A. O., Luo, X., Petrak, J., Vyoral, D., et al. (2009c). Prion protein modulates cellular iron uptake: a novel function with implications for prion disease pathogenesis. PLoS ONE 4:e4468. doi: 10.1371/journal.pone. 0004468

Singh, A., Qing, L., Kong, Q., and Singh, N. (2012). Change in the characteristics of ferritin induces iron imbalance in prion disease affected brains. Neurobiol. Dis. 45, 930-938. doi: 10.1016/j.nbd.2011. 12.012
Slater, E. C. (1949). The measurement of the cytochrome oxidase activity of enzyme preparations. Biochem. J. 44, 305-318.

Smith, M. A., Harris, P. L., Sayre, L. M., and Perry, G. (1997). Iron accumulation in Alzheimer disease is a source of redox-generated free radicals. Proc. Natl. Acad. Sci. U.S.A. 94, 9866-9868. doi: 10.1073/pnas.94.18.9866

Smith, M. A., Wehr, K., Harris, P. L., Siedlak, S. L., Connor, J. R., and Perry, G. (1998). Abnormal localization of iron regulatory protein in Alzheimer's disease. Brain Res. 788, 232-236. doi: 10.1016/S00068993(98)00002-X

Smith, M. A., Zhu, X., Tabaton, M., Liu, G., Mckeel, D. W. Jr., Cohen, M. L., et al. (2010). Increased iron and free radical generation in preclinical Alzheimer disease and mild cognitive impairment. J. Alzheimers Dis. 19, 363-372.

Staedt, J., Stoppe, G., Kogler, A., Riemann, H., Hajak, G., Munz, D. L., et al. (1995). Nocturnal myoclonus syndrome (periodic movements in sleep) related to central dopamine D2-receptor alteration. Eur. Arch. Psychiatry Clin. Neurosci. 245, 8-10. doi: 10.1007/BF02191538

Strugatsky, D., Gottschalk, K. E., Goldshleger, R., Bibi, E., and Karlish, S. J. (2003). Expression of $\mathrm{Na}+, \mathrm{K}+-$ ATPase in Pichia pastoris: analysis of wild type and D369N mutant proteins by $\mathrm{Fe} 2+$-catalyzed oxidative cleavage and molecular modeling. J. Biol. Chem. 278, 46064-46073. doi: 10.1074/jbc.M308303200

Synofzik, M., Godau, J., Lindig, T., Schols, L., and Berg, D. (2011). Transcranial sonography reveals cerebellar, nigral, and forebrain abnormalities in Friedreich's ataxia. Neurodegener. Dis. 8, 470-475. doi: 10.1159/000327751

Tamura, Z., Yoshioka, M., Imanari, T., Fukaya, J., and Kusaka J. (1973). Identification of green pigment and analysis of clioquinol in specimens from patients with subacute myelo-optico-neuropathy. Clin. Chim. Acta 47, 13-20. doi: 10.1016/0009-8981(73)90052-1

Taylor, E. M., and Morgan, E. H. (1990). Developmental changes in transferrin and iron uptake by the brain in the rat. Brain Res. 55, 35-42. doi: 10.1016/0165-3806(90)90103-6

Texel, S. J., Zhang, J., Camandola, S., Unger, E. L., Taub, D. D., Koehler, R. C., et al. (2011). Ceruloplasmin deficiency reduces levels of iron and BDNF in the cortex and striatum of young mice and increases their vulnerability to stroke. PLoS 
ONE 6:e25077. doi: 10.1371/journal.pone.0025077

Theil, E. C. (2004). Iron, ferritin, and nutrition. Annu. Rev. Nutr. 24, 327-343. doi: 10.1146/annurev. nutr.24.012003.132212

Turjanski, N., Lees, A. J., and Brooks, D. J. (1999). Striatal dopaminergic function in restless legs syndrome: 18F-dopa and 11C-raclopride PET studies. Neurology 52, 932-937. doi: 10.1212/WNL.52.5.932

Turnbull, S., Tabner, B. J., El-Agnaf, O. M., Moore, S., Davies, Y., and Allsop, D. (2001). alpha-Synuclein implicated in Parkinson's disease catalyses the formation of hydrogen peroxide in vitro. Free Radic. Biol. Med. 30, 1163-1170. doi: 10.1016/S08915849(01)00513-5

Ueda, F., Raja, K. B., Simpson, R. J., Trowbridge, I. S., and Bradbury, M. W. B. (1993). Rate of 59Fe uptake into brain and cerebrospinal fluid and the influence thereon of antibodies against the transferrin receptor. J. Neurochem. 60, 106-113. doi: 10.1111/j.1471-4159.1993.tb05828.x

Ulfberg, J., Nystrom, B., Carter, N., and Edling, C. (2001). Restless Legs Syndrome among working-aged women. Eur. Neurol. 46, 17-19. doi: 10.1159/000050750

van Eersel, J., Bi, M., Ke, Y. D., Hodges, J. R., Xuereb, J. H., Gregory, G. C., et al. (2009). Phosphorylation of soluble tau differs in Pick's disease and Alzheimer's disease brains. J. Neural. Transm. 116, 1243-1251.

Van Landeghem, G. F., Sikstrom, C., Beckman, L. E., Adolfsson, R., and Beckman, L. (1998). Transferrin C2, metal binding and Alzheimer's disease. Neuroreport 9, 177-179.

von Lewinski, F., Werner, C., Jorn, T., Mohr, A., Sixel-Doring, F., and Trenkwalder, C. (2007). T2*weighted MRI in diagnosis of multiple system atrophy. A practical approach for clinicians. J. Neurol. 254, 1184-1188. doi: 10.1007/ s00415-006-0496-1

Vymazal, J., Righini, A., Brooks, R. A., Canesi, M., Mariani, C., Leonardi, M., et al. (1999). T1 and T2 in the brain of healthy subjects, patients with Parkinson disease, and patients with multiple system atrophy: relation to iron content. Radiology 211, 489-495.

Wachs, T. D., Pollitt, E., Cueto, S. Jacoby, E., and Creed-Kanashiro, H. (2005). Relation of neonatal iron status to individual variability in neonatal temperament. Dev. Psychobiol. 46, 141-153. doi: 10.1002/dev.20049

Wallis, L. I., Paley, M. N., Graham, J. M., Grunewald, R. A., Wignall, E. L.,
Joy, H. M., et al. (2008). MRI assessment of basal ganglia iron deposition in Parkinson's disease. J. Magn Reson. Imaging 28, 1061-1067. doi: 10.1002/jmri.21563

Walter, P. B., Knutson, M. D., PalerMartinez, A., Lee, S., Xu, Y., Viteri, F. E., et al. (2002). Iron deficiency and iron excess damage mitochondria and mitochondrial DNA in rats. Proc. Natl. Acad. Sci. U.S.A. 99, 2264-2269. doi: 10.1073/pnas.26170 8798

Wan, L., Nie, G., Zhang, J., Luo, Y., Zhang, P., Zhang, Z. et al. (2011). beta-Amyloid peptide increases levels of iron content and oxidative stress in human cell and Caenorhabditis elegans models of Alzheimer disease. Free Radic. Biol. Med. 50, 122-129. doi: 10.1016/ j.freeradbiomed.2010.10.707

Wan, L., Nie, G., Zhang, J., and Zhao, B. (2012a). Overexpression of human wild-type amyloid-beta protein precursor decreases the iron content and increases the oxidative stress of neuroblastoma SH-SY5Y cells. J. Alzheimers Dis. 30, 523-530.

Wan, L., Nie, G., Zhang, J., and Zhao, B. (2012b). Overexpression of human wild-type amyloid-beta protein precursor decreases the iron content and increases the oxidative stress of neuroblastoma SH-SY5Y cells. J. Alzheimers Dis. 30, 523-530.

Wang, Y., Butros, S. R., Shuai, X., Dai, Y., Chen, C., Liu, M., et al. (2012). Different iron-deposition patterns of multiple system atrophy with predominant parkinsonism and idiopathetic Parkinson diseases demonstrated by phase-corrected susceptibility-weighted imaging. AJNR Am. J. Neuroradiol. 33, 266-273. doi: 10.3174/ajnr.A2765

Werner, C. J., Heyny-Von Haussen, R., Mall, G., and Wolf, S. (2008). Proteome analysis of human substantia nigra in Parkinson's disease. Proteome Sci. 6, 8. doi: 10.1186/1477-5956-6-8

Whitnall, M., Suryo Rahmanto, Y., Huang, M. L., Saletta, F., Lok, H. C., Gutierrez, L., et al. (2012). Identification of nonferritin mitochondrial iron deposits in a mouse model of Friedreich ataxia. Proc. Natl. Acad. Sci. U.S.A. 109, 20590-20595. doi: 10.1073/pnas.1215349109

Wood, M. M., and Elwood, P. C. (1966). Symptoms of iron deficiency anaemia. A community survey. $\mathrm{Br}$. J. Prev. Soc. Med. 20, 117-121.

Wu, L. J.-C., Leenders, A. G. M., Cooperman, S., Meyron-Holtz, E., Smith, S., Land, W., et al. (2004). Expression of the iron transporter ferroportin in synaptic vesicles and the blood-brain barrier. Brain Res. 1001, 108-117. doi: 10.1016/j.brainres.2003.10.066

Xie, L., Zheng, W., Xin, N., Xie, J. W., Wang, T., and Wang, Z. Y. (2012). Ebselen inhibits ironinduced tau phosphorylation by attenuating DMT1 up-regulation and cellular iron uptake. Neurochem. Int. 61, 334-340. doi: 10.1016/ j.neuint.2012.05.016

Yagoda, N., Von Rechenberg, M., Zaganjor, E., Bauer, A. J., Yang, W. S., Fridman, D. J., et al. (2007). RAS-RAFMEK-dependent oxidative cell death involving voltage-dependent anion channels. Nature 447, 864-868. doi: 10.1038 /nature05859

Yamamoto, A., Shin, R.-W., Hasegawa, K., Naiki, H., Sato, H., Yoshimasu, F., et al. (2002). Iron (III) induces aggregation of hyperphosphorylated tau and its reduction to iron (II) reverses the aggregation: implications in the formation of neurofibrillary tangles of Alzheimer's disease. J. Neurochem. 82, 1137-1147. doi: 10.1046/j.14714159.2002.t01-1-01061.x

Yang, W. S., and Stockwell, B. R. (2008). Synthetic lethal screening identifies compounds activating iron-dependent, nonapoptotic cell death in oncogenic-RAS-harboring cancer cells. Chem. Biol. 15, 234 245. doi: 10.1016/j.chembiol.2008. 02.010

Yehuda, S., Youdim, M. E., and Mostofsky, D. I. (1986). Brain iron-deficiency causes reduced learning capacity in rats. Pharmacol. Biochem. Behav. 25, 141-144. doi: 10.1016/0091-3057(86)90244-3

Youdim, M. B., Ben-Shachar, D., and Yehuda, S. (1989). Putative biological mechanisms of the effect of iron deficiency on brain biochemistry and behavior. Am. J. Clin. Nutr. 50, 607-615; discussion 615-607.

Youdim, M. B., Fridkin, M., and Zheng, H. (2004a). Novel bifunctional drugs targeting monoamine oxidase inhibition and iron chelation as an approach to neuroprotection in Parkinson's disease and other neurodegenerative diseases. $\mathrm{J}$. Neural. Transm. 111, 1455-1471. doi 10.1007/s00702-004-0143-x

Youdim, M. B., Stephenson, G., and Ben Shachar, D. (2004b). Ironing iron out in Parkinson's disease and other neurodegenerative diseases with iron chelators: a lesson from 6-hydroxydopamine and iron chelators, desferal and VK-28. Ann. N. Y. Acad. Sci. 1012, 306-325. doi: 10.1196/annals.1306.025

Youdim, M. B., Fridkin, M., and Zheng, H. (2005). Bifunctional drug derivatives of MAO-B inhibitor rasagiline and iron chelator VK-28 as a more effective approach to treatment of brain ageing and ageing neurodegenerative diseases. Mech. Ageing Dev. 126, 317-326. doi: 10.1016/j.mad.2004.08.023

Yu, G. S., Steinkirchner, T. M., Rao, G. A., and Larkin, E. C. (1986). Effect of prenatal iron deficiency on myelination in rat pups. Am. J. Pathol. 125, 620-624.

Yu, J., Guo, Y., Sun, M., Li, B., Zhang, Y., and Li, C. (2009). Iron is a potential key mediator of glutamate excitotoxicity in spinal cord motor neurons. Brain Res. 1257, 102107. doi: 10.1016/j.brainres.2008.12. 030

Yurkova, I., Kisel, M., Arnhold, J., and Shadyro, O. (2005). Ironmediated free-radical formation of signaling lipids in a model system. Chem. Phys. Lipids 137, 29-37. doi: 10.1016/j.chemphyslip.2005.06. 002

Zecca, L., Stroppolo, A., Gatti, A., Tampellini, D., Toscani, M., Gallorini, M., etal. (2004). The role of iron and copper molecules in the neuronal vulnerability of locus coeruleus and substantia nigra during aging. Proc. Natl. Acad. Sci. U.S.A. 101, 9843-9848. doi: 10.1073/pnas.04034 95101

Zhang, J., Zhang, Y., Wang, J., Cai, P., Luo, C., Qian, Z., Dai, Y., and Feng, H. (2010). Characterizing iron deposition in Parkinson's disease using susceptibility-weighted imaging: an in vivo MR study. Brain Res. 1330, 124-130. doi: 10.1016/ j.brainres.2010.03.036

Zhu, W., Xie, W., Pan, T., Xu, P., Fridkin, M., Zheng, H., et al. (2007). Prevention and restoration of lactacystininduced nigrostriatal dopamine neuron degeneration by novel brainpermeable iron chelators. FASEB J. 21, 3835-3844. doi: 10.1096/fj.07$8386 \mathrm{com}$

Zhu, W. Z., Zhong, W. D., Wang, W., Zhan, C. J., Wang, C. Y., Qi, J. P., et al. (2009). Quantitative MR phase-corrected imaging to investigate increased brain iron deposition of patients with Alzheimer disease. Radiology 253, 497-504. doi: 10.1148/radiol.2532082324

Zhukareva, V., Sundarraj, S., Mann, D., Sjogren, M., Blenow, K., Clark, C. M., et al. (2003). Selective reduction of soluble tau proteins in sporadic and familial frontotemporal dementias: an international follow-up study. Acta Neuropathol. 105, 469-476.

Zhukareva, V., Vogelsberg-Ragaglia, V., Van Deerlin, V. M., Bruce, J., Shuck, T., Grossman, M., et al. (2001). 
Loss of brain tau defines novel sporadic and familial tauopathies with frontotemporal dementia. Ann. Neurol. 49, 165-175. doi: 10.1002/15318249(20010201)49:2

Conflict of Interest Statement: The authors declare that the research was conducted in the absence of any commercial or financial relationships that could be construed as a potential conflict of interest.

Received: 30 April 2013; paper pending published: 29 May 2013; accepted: 25 June 2013; published online: 18 July 2013.
Citation: Hare D, Ayton S, Bush A and Lei $P$ (2013) A delicate balance: iron metabolism and diseases of the brain. Front. Aging Neurosci. 5:34. doi 10.3389/fnagi.2013.00034

Copyright (c) 2013 Hare, Ayton, Bush and Lei. This is an open-access article distributed under the terms of the Creative Commons Attribution License, which permits use, distribution and reproduction in other forums, provided the original authors and source are credited and subject to any copyright notices concerning any third-party graphics etc. 